\title{
The first studies of small mammals of the Cham Chu and Bac Me Nature Reserves, north-eastern Vietnam
}

\author{
Nguyen Thi Tham*, Ly Ngoc Tu, Vu Thuy Duong, Bui Tuan Hai, \\ Nguyen Dinh Duy, Alexei V. Abramov, Sergei V. Kruskop, Le Duc Minh \\ \& Nguyen Truong Son*
}

\begin{abstract}
Field surveys of mammals in two protected areas of the north-eastern limestone region of Vietnam, the Cham Chu (Tuyen Quang Province) and Bac Me (Ha Giang Province) Nature Reserves were conducted in 2018 and 2019. Thirty-five species of small mammals were recorded based both on field observations and on morphological and/or molecular evidence, as follows: one Scandentia species, four Eulipotyphla species, 14 Chiroptera species, and 16 Rodentia species. New records of Aselliscus dongbacanus and Chiromyscus thomasi in north-eastern Vietnam have been confirmed. Interestingly, the mole specimens collected during this study resemble Euroscaptor orlovi morphologically but significantly differ from it genetically. The present study has revealed that Chiroptera (38.9\%) and Rodentia (47.2\%) are the dominant groups in terms of their species diversity. Yet, the number of bat species is much lower as compared to that revealed by the previous study conducted in the same region (16 vs. 35). Although a couple of abundant species - Aselliscus dongbacanus (40 of 176 specimens) and Hipposideros cf. larvatus (37 of 176 specimens) - have been found during the present survey, other common species, such as Callosciurus inornatus and Rhizomys pruinosus, were very scarce, suggesting the occurrence of a severe anthropogenic pressure on small mammal fauna. More studies to assess a conservation status of and anthropogenic threats to small mammals are needed to protect them from serious population decline in the future.
\end{abstract}

How to cite this article: Tham N.T., Tu L.N., Duong V.T., Hai B.T., Abramov A.V., Kruskop S.V., Minh L.D., Son N.T. 2020. The first studies of small mammals of the Cham Chu and Bac Me Nature Reserves, north-eastern Vietnam // Russian J. Theriol. Vol.19. No.2. P.193-209. doi: 10.15298/rusjtheriol.19.2.10.

KEY WORDS: checklist, north-eastern Vietnam, limestone region, Cham Chu, Bac Me.

Nguyen Thi Tham [thamnguyenctlhp@gmail.com],Le Duc Minh [le.duc.minh@hus.edu.vn] Faculty of Environmental Sciences, University of Science, Vietnam National University, Hanoi, 334 Nguyen Trai Road, Hanoi Vietnam and Central Institute for Natural Resources and Environmental Studies, Vietnam National University, Hanoi, 19 Le Thanh Tong, Hanoi, Vietnam; LyNgoc Tu [ngoctu1890@gmail.com], Center of Science and Technology, Hanoi Metropolitan University, 98 Duong Quang Ham, Cau Giay, Hanoi, Vietnam, Department of Vertebrate Zoology, Institute of Ecology, Vietnam Academy of Science and Technology, 18 Hoang Quoc Viet, Cau Giay, Hanoi, Vietnam; Vu Thuy Duong [vuthuyduong. xd@gmail.com], Nguyen DinhDuy [nguyenduyfuv@gmail.com] and Nguyen Truong Son [truongsoniebr@gmail.com], Department of Vertebrate Zoology, Institute of Ecology and Biological Resources and Graduate University of Science and Technology, Vietnam Academy of Science and Technology, 18 Hoang Quoc Viet, Cau Giay, Hanoi, Vietnam; Bui Tuan Hai [tuanhai@eulipotyphla.com], Department of Nature Conservation, Vietnam National Museum of Nature and Graduate University of Science and Technology, 18 Hoang Quoc Viet, Cau Giay, Hanoi, Vietnam; Alexei V. Abramov [alexei.abramov@zin.ru], Zoological Institute, Russian Academy of Sciences, Universitetskaya nab. 1, Saint Petersburg 199034, Russia, and Joint Vietnamese-Russian Tropical Research and Technological Centre, Nguyen Van Huyen, Nghia Do, Cau Giay, Hanoi, Vietnam; SergeiV. Kruskop [kruskop@zmmu.msu.ru], Zoological Museum, Moscow State University, ul. Bolshaya Nikitskaya 2, Moscow 125009, Russia, and Joint Vietnamese-Russian Tropical Research and Technological Centre, Nguyen Van Huyen, Nghia Do, Cau Giay, Hanoi, Vietnam.

\section{Первые исследования мелких млекопитающих в заповедниках Чамчу и Бакме, северо-восточный Вьетнам}

\author{
Т.Т. Нгуен*, Р.Т. Ли, Т.Д. Ву, Т.Х. Буй, Д.Д. Нгуен, А.В. Абрамов, \\ С.В. Крускоп, Д.М. Ле, Т.С. Нгуен*
}

РЕЗЮМЕ. Полевые исследования на двух охраняемых территориях в северо-восточном карстовом регионе Вьетнама, в заповеднике Чамчу (провинция Туенкуанг) и заповеднике Бакме (провинция

\footnotetext{
* Corresponding authors
} 
Хазанг) были проведены в 2018 и 2019 годах. На основании данных полевых наблюдений, морфологических и генетических исследований зарегистрировано 35 видов мелких млекопитающих, включающих один вид Scandentia, четыре вида Eulipotyphla, 14 видов Chiroptera и 16 видов Rodentia. Подтверждены новые находки Aselliscus dongbacanus и Chiromyscus thomasi на северо-востоке Вьетнама. Интересно, что экземпляры кротов, собранные в ходе этого исследования, морфологически напоминают Euroscaptor orlovi, но генетически они значительно отличаются от этого вида. Результаты наших исследований свидетельствуют, что доминирующими группами по видовому составу являются Chiroptera (38.9\%) и Rodentia (47.2\%). Однако количество отмеченных видов летучих мышей было намного меньше по сравнению с предыдущими исследованиями, проведенным в этом же регионе (16 против 35). Хотя было отмечено несколько многочисленных видов - Aselliscus dongbacanus (40 из 176 экз.) и Hipposideros cf. larvatus (37 из 176 экз.) - другие обычные виды, такие как Callosciurus inornatus и Rhizomys pruinosus, были очень редки, что свидетельствует о серьезном антропогенном давлении на фауну мелких млекопитающих. Необходимы дополнительные исследования по оценке уровня сохранности и антропогенной опасности для мелких млекопитающих с тем, чтобы в будущем предотвратить серьезное снижение их численности.

КЛЮЧЕВЫЕ СЛОВА: чеклист, северо-восточный Вьетнам, карстовый район, Чамчу, Бакме.

\section{Introduction}

Vietnam is situated in the Indochina Peninsula, harbouring a very high diversity of forest mammals. To date, over 331 mammal (sub)species have been recognized in the country (Nguyen Quang Truong et al., 2020), compared to 500 mammal species found in the Indochina Peninsula (Francis, 2019). In terms of species richness and endemism, Vietnam is commonly recognized as a biodiversity hotspot not only in SE Asia but also in the world (Tordoff et al., 2007, 2012). However, the mammal fauna of Vietnam has experienced a steep decline in recent decades. Specifically, the Javan rhinoceros Rhinoceros sondaicus annamiticus became extinct from Vietnam in 2011 (Brook et al., 2011, 2012; Ellis \& Talukdar, 2020) and more than 60 species are currently listed as vulnerable or a higher category in the IUCN Red List (IUCN, 2020), although the country's forest cover has moderately raised from $37 \%$ in 2006 (1970/QĐ/BNN-KL) to 41.9\% in 2019 (1423/QĐ-BNNTCLN). The overexploitation resulted from poaching is regarded as the most severe threat to mammals and other vertebrates in Vietnam (Gray et al., 2018).

The north-eastern limestone region of Vietnam contains large karst outcrops surrounded by hills and low mountains consisting of soil (Sterling \& Hurley, 2005; Sterling et al., 2006). Karst towers form an extensive but highly dissected plateau (Sterling et al., 2006). The region possesses one of the highest concentrations of endemic species (Clements et al., 2006). There are several remarkable mammals that are endemic to the northeast region, including the Tonkin snub-nosed monkey Rhinopithecus avunculus (Le Khac Quyet et al., 2020; IUCN, 2020), the Daovantien's limestone rat Tonkinomys daovantieni (Musser et al., 2006) and the Cao-vit black crested gibbon Nomascus nasutus (Rawson et al., 2020; IUCN, 2020).

The field surveys conducted in Tuyen Quang and Ha Giang Provinces between 1998 and 2011 have recorded 68 small mammal species, consisting of one Scandentia, 10 Eulipotyphla, 35 Chiroptera and 22 Rodentia (Nguyen
Truong Son et al., 2011). A number of new endemic small mammal species in this karst area, such as Tonkinomys daovantieni (Musser et al., 2006), Aselliscus dongbacanus (Vuong Tan Tu et al., 2015), Euroscaptor orlovi and E. kuznetsovi (Zemlemerova et al., 2016), continues to be discovered. Yet, the small mammal fauna of north-eastern Vietnam has been studied in some protected areas: viz., the Huu Lien Nature Reserve (NR) (Lang Son Province) (Lunde et al., 2007), the Ba Be National Park (NP) (Bac Kan Province) (Nguyen Truong Son \& Vu Dinh Thong, 2008), the Tay Con Linh NR (Ha Giang Province) (Lunde et al., 2003; Nguyen Truong Son et al., 2017) and the Na Hang NR (Tuyen Quang Province) (Nguyen Truong Son \& Vu Dinh Thong, 2008).

To better understand the small mammal fauna of north-eastern Vietnam, field surveys were conducted in the Cham Chu (Tuyen Quang Province) and Bac Me (Ha Giang Province) Nature Reserves in 2018 and 2019. During the surveys tree shrew, bats, rodents, shrews and moles were recorded. Species were identified on the basis of both morphological and genetic characters. In the present paper, the first list of small mammals recorded from these reserves is provided for the first time.

\section{Material and methods}

Field surveys were conducted in Nam Nuong, Phu Luu and Cao Duong hamlets (Cham Chu NR), and in Khau Ca Forest and Lung Cang hamlet (Bac Me NR and its vicinity). The Cham Chu NR is located in Tuyen Quang Province covering the area of 15262.3 ha; the Bac Me NR covers the area of 9042.5 ha in Ha Giang Province. Both protected areas are situated in the limestone karst region of north-eastern Vietnam, and are mainly covered with the secondary montane evergreen forest consisting of both broad-leaved and coniferous trees (Sterling et al., 2006). The elevations range from 100 to $850 \mathrm{~m}$ above sea level. Of the study sites, Cao Duong hamlet lies at the highest elevations between 600 and $850 \mathrm{~m}$, whereas at Phu Luu hamlet lies lower, at the elevations of 100 to $550 \mathrm{~m}$. These sites were selected 
in the areas with a complex limestone terrain, including caves, lowland mountains, torrent streams and high waterfalls (Fig. 1).

The field surveys were conducted in the Cham Chu NR in August 2018 and April 2019, and in the Bac Me NR in May and October 2019 (Tab. 1).

During the survey, different methods were used to collect small mammals: viz., Sherman box traps, Tomahawk traps, mole-traps, mist nets and harp trap at daytime and nighttime following the methods recommended by the Animal Care and Use Guidelines of the American Society of Mammalogists (Sikes et al., 2016). Three types of the Sherman live-traps $(3 \times 3 \times 10 \mathrm{~cm} ; 5 \times 5 \times$ $18 \mathrm{~cm} ; 7 \times 7 \times 30 \mathrm{~cm}$ ) were employed to catch medium and small-sized rodents and shrews. Tomahawk $(15 \times$ $15 \times 45 \mathrm{~cm}$ ) and local cage traps were used to capture large-sized rodents and squirrels. Cassava, crisps, pineapples and peanuts were chosen as bait. Peanut butter was mixed with baits to enhance the flavor or aroma. Baits were changed every day after checking the traps.

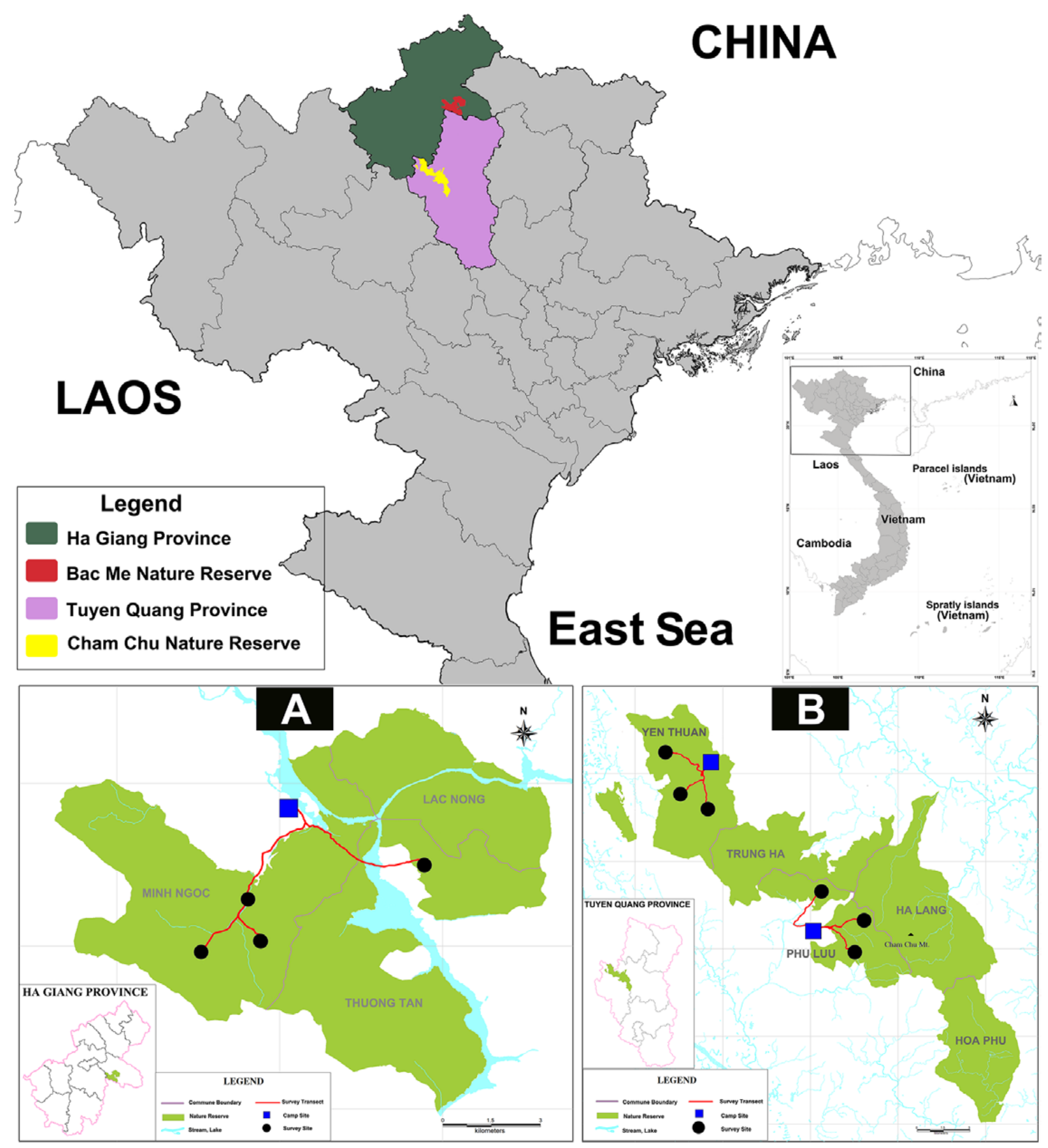

Fig. 1. Geographic locations of the Cham Chu (A) and Bac Me (B) NRs and the survey transects (red lines). 
Table 1. Total survey efforts in the study areas: D.O. — daytime observation (hours); MN — mist nets $\left(\mathrm{m}^{2} / \mathrm{n} / \mathrm{h}\right)$; $\mathrm{H}$ - harp trap $\left(\mathrm{m}^{2} / \mathrm{n} / \mathrm{h}\right) ; \mathrm{M}$ - mole-traps (trap nights); S \& C - Sherman and cage traps (trap nights); N.O. - nighttime observations (hours); $n$ - number of captured specimens.

\begin{tabular}{|c|c|c|c|c|c|c|c|c|}
\hline Site & Date of survey & D.O. & $\mathrm{MN}$ & $\mathrm{H}$ & M & $S \& C$ & N.O. & $n$ \\
\hline \multirow{3}{*}{ Cham Chu NR } & 24-31.10.2018 & 22 & 810 & 189 & 16 & 252 & 8.25 & 30 \\
\hline & $13-19.04 .2019$ & 14 & 1161 & 162 & 42 & 315 & 25.5 & 58 \\
\hline & Total efforts & 36 & 1971 & 351 & 58 & 567 & 33.75 & 86 \\
\hline \multirow{3}{*}{$\begin{array}{l}\text { Bac Me NR and } \\
\text { surrounding area }\end{array}$} & 24-31.05.2019 & 17.5 & 864 & 162 & 15 & 210 & 8.75 & 48 \\
\hline & $14-21.10 .2019$ & 24.5 & 1512 & 162 & 16 & 204 & 22.75 & 49 \\
\hline & Total efforts & 42 & 2376 & 324 & 31 & 414 & 31.5 & 90 \\
\hline \multicolumn{2}{|c|}{ Total } & 78 & 4347 & 675 & 89 & 981 & 65.25 & 176 \\
\hline
\end{tabular}

Different types of mist nets $(2 \times 3 \mathrm{~m}, 6 \times 3 \mathrm{~m}$ and $12 \times$ $4 \mathrm{~m})$ and harp trap $(1.5 \times 1.5 \mathrm{~m})$ were used to capture live bats. These traps were set across trails, over streams, inside and at forest edges, and at cave entrances, in accordance with the published recommendations by Kunz \& Parsons (2009). Japanese hand-made traps and Talpex traps were set up on the trails where mole tunnels were observed. The total survey efforts are shown in Table 1.

Specimen photos were taken to record pelage features in detail. Several external characters, including the head and body length (HB), the tail length (TL), the hind foot length $(\mathrm{HF})$, the ear length $(\mathrm{E})$, the forearm length (FA) (for bats) and the greatest skull length (GL), were measured with a digital caliper (Mitutoyo NTD1215PMX, Kawasaki, Japan) to an accuracy of $0.01 \mathrm{~mm}$. Body mass (BW) in grams were measured following the standard methods.

The morphological descriptions of Csorba et al. (2003), Kruskop (2013), Wilson et al. (2016, 2017, 2018), Francis (2019) and Wilson \& Mittermeier (2019) were used for a morphological analysis in the present study. Besides, for a morphological comparison, we have also obtained data from the following papers: viz., Balakirev et al. (2014), Zemlemerova et al. (2016), Vuong Tan Tu et al. (2015), Nguyen Truong Son et al. (2015). The nomenclature of mammals followed Wilson et al. $(2016,2017,2018)$ and Wilson \& Mittermeier (2019), unless stated otherwise.

By using the DNA barcoding, we have been able to identify 26 specimens belonging to the groups with a complicated morphological variation (Tab. 3). We took liver or wing membrane punch (for bats) tissue samples from 26 specimens and stored them in $70 \%$ ethanol for a further verification of the species identification by means of the DNA barcoding method. Two mitochondrial genes, cytochrome $b(c y t b)$ and cytochrome $c$ oxidase subunit 1 (COI) were amplified and sequenced using the primers L14724-H15149 for $c y t b$ and partial tRNA-Thr from Irwin et al. (1991) and the primers VF1d-VR1d for COI from Ivanova et al. (2006). Tissue samples were extracted using the DNeasy blood and tissue kit, Qiagen (Hilden, Germany). Extracted DNA from fresh tissue was amplified by the DreamTaq PCR mastermix, Thermo Fisher Scientific (Vilnius, Lithuania). The PCR volume consisted of $21 \mu \mathrm{l}(10 \mu \mathrm{l}$ of mastermix, $5 \mu \mathrm{l}$ of water, $2 \mu \mathrm{l}$ of each primer at $10 \mathrm{pmol} / \mu \mathrm{l}$, and $2 \mu \mathrm{l}$ of DNA or higher depending on a DNA quantity in the final extraction solution). The PCR conditions were: $95^{\circ} \mathrm{C}$ for 5 min to activate the taq; with 40 cycles at $95^{\circ} \mathrm{C}$ for $30 \mathrm{~s}, 50^{\circ} \mathrm{C}$ for $45 \mathrm{~s}, 72^{\circ} \mathrm{C}$ for $60 \mathrm{~s}$; and the final extension at $72^{\circ} \mathrm{C}$ for $6 \mathrm{~min}$. PCR products were subjected to electrophoresis through the $1 \% 135$ agarose gel, 1st BASE (Selangor, Malaysia). Gels were stained for $10 \mathrm{~min}$ in $1 \mathrm{X}$ TBE buffer at $2 \mathrm{pg} / \mathrm{ml}$ of ethidium-bromide and visualized under UV light. Successful amplifications were purified to eliminate PCR components using the GeneJET ${ }^{\mathrm{TM}}$ PCR Purification Kit, Thermo Fisher Scientific (Vilnius, Lithuania). Purified PCR products were sent to Macrogen Inc. (Seoul, South Korea) for sequencing. The 140 sequences generated in this study were aligned with one another using the De Novo Assemble function in the program Geneious v.7.1.8 (Kearse et al., 2012). Then they were compared with other sequences using the Basic Local Alignment Search Tool (BLAST) in GenBank (NCBI).

A phylogenetic tree was constructed to recover phylogenetic relationships of complex groups, for instance, Niviventer-Chiromyscus, by employing the Bayesian inference as implemented in MrBayes v.3.2.7 (Ronquist et al., 2012). The final matrix contained 1164 aligned characters of 16 taxa. Two outgroups selected were Mus musculus (LC325158) and Apodemus draco (HQ333255). We used the optimal model for nucleotide evolution as determined by jModeltest 2.1.4 (Darriba et al., 2012) with parameters estimated by MrBayes v.3.2.7. Two simultaneous analyses with four Markov chains (one cold and three heated) were run for 10 million generations with a random starting tree and trees were sampled every 1000 generations. The cutoff point for the burn-in function was set to 5 in the Bayesian analyses, as - $\operatorname{lnL}$ scores reached stationarity after 5000 generations in both runs. Posterior probability values for major clades in the final majority rule consensus tree were provided. 


\section{Results}

In total, we collected 176 specimens, which were assigned to 35 small mammal species of 13 families in four orders: viz., 23 species in the Cham Chu NR and 23 species in the Bac Me NR (Tab. 2). Fifty five individuals were released back to the wild after taking measurements and photos. According to the recent IUCN Red List (IUCN, 2020), all recorded species listed as Least Concern, and only Belomys pearsonii — as Data Deficient.

Table 2. Species of small mammals documented in the Cham Chu and Bac Me NRs during the field surveys in 2018 and 2019. Numbers denote the quantity of individuals captured; $\mathrm{O}$ - observed; * - identification confirmed by the DNA analysis.

\begin{tabular}{|c|c|c|c|c|}
\hline No. & Scientific name & Cham Chu NR & Bac Me NR & Comments \\
\hline 1 & Tupaia belangeri & - & 2 & common species \\
\hline 2 & Crocidura tanakae ${ }^{*}$ & 1 & 2 & \\
\hline 3 & Suncus murinus & $\mathrm{O}$ & $\mathrm{O}$ & common species \\
\hline 4 & Chimarrogale himalayica $*$ & 1 & - & \\
\hline 5 & Euroscaptor cf. orlovi $*$ & 6 & 2 & \\
\hline 6 & Cynopterus sphinx * & 12 & 4 & common species \\
\hline 7 & Macroglossus sobrinus & 2 & - & \\
\hline 8 & Rhinolophus microglobosus & - & 5 & \\
\hline 9 & Rhinolophus pearsonii & 2 & 1 & \\
\hline 10 & Rhinolophus pusillus * & - & 1 & \\
\hline 11 & Rhinolophus rex & 2 & - & \\
\hline 12 & Rhinolophus thomasi & 2 & - & \\
\hline 13 & Rhinolophus affinis * & - & 1 & \\
\hline 14 & Aselliscus dongbacanus * & 20 & 20 & common species \\
\hline 15 & Hipposideros armiger* & 2 & 12 & common species \\
\hline 16 & Hipposideros cf. larvatus & 17 & 20 & common species \\
\hline 17 & Hipposideros gentilis & - & 2 & \\
\hline 18 & Lyroderma lyra & 4 & - & \\
\hline 19 & Myotis chinensis * & 1 & - & \\
\hline 20 & Belomys pearsonii & - & 1 & \\
\hline 21 & Callosciurus erythraeus & 2 & 4 & common species \\
\hline 22 & Callosciurus inornatus $*$ & - & 2 & common species \\
\hline 23 & Tamiops maritimus & - & 1 & \\
\hline 24 & Rhizomys pruinosus $*$ & 1 & - & common species \\
\hline 25 & Berylmys bowersi & - & 1 & \\
\hline 26 & Chiropodomys gliroides & 1 & - & \\
\hline 27 & Chiromyscus thomasi $*$ & 1 & - & \\
\hline 28 & Chiromyscus langbianis * & 1 & 4 & \\
\hline 29 & Leopoldamys edwardsi & 1 & - & \\
\hline 30 & Maxomys surifer & 1 & - & \\
\hline 31 & Mus pahari & - & 1 & \\
\hline 32 & Niviventer fulvescens * & 2 & 1 & \\
\hline 33 & Rattus andamanensis & - & 3 & \\
\hline 34 & Rattus nitidus & 4 & - & \\
\hline 35 & Atherurus macrourus & - & $\mathrm{O}$ & \\
\hline
\end{tabular}


Key small mammal species

\section{ORDER SCANDENTIA Family TUPAIIDAE}

Tupaia belangeri (Wagner, 1841)

This is a common species in Vietnam known from various habitat types such as primary and secondary, evergreen and deciduous forests in limestone mountains, from the sea level up to high elevations (Molur et al., 2005). Only two specimens were collected in the secondary forest in limestone mountains at the altitude of $620 \mathrm{~m}$ a.s.l. in Khau Ca Forest, the Bac Me NR.

\section{ORDER EULIPOTYPHLA Family SORICIDAE}

Crocidura tanakae Kuroda, 1938

C. tanakae is widespread in China and Vietnam (Bannikova et al., 2011; Li et al., 2019). This species was first reported from Tuyen Quang based on the same specimen collected during our field surveys (Bui Tuan Hai et al., 2019). We obtained one specimen from the Cham Chu NR: HB is $69.3 \mathrm{~mm}$, TL is $53.8 \mathrm{~mm}$, and GL is $20.64 \mathrm{~mm}$. The cytb sequence of this specimen is $98.8 \%$ similar to that of C. tanakae from Longmen, Guangdong, China (Tab. 3).

\section{Chimarrogale himalayica (Gray, 1842)}

The Himalayan water shrew $C$. himalayica is widespread in south China and north Vietnam (Abramov et al., 2017). A single specimen collected during our survey from the Cham Chu NR was the first record of this species from Tuyen Quang Province (Bui Tuan Hai et al., 2019). This specimen has $\mathrm{HB}=122.25 \mathrm{~mm}, \mathrm{TL}=$ $86.13 \mathrm{~mm}$, and GL $=26.19 \mathrm{~mm}$. Abramov et al. (2017) reported just four specimens of $C$. himalayica in northern Vietnam collected from 2013 to 2015 . Scanty records of this species are evidence that the species is rare in Vietnam and its conservation status needs to be assessed.

\section{Family TALPIDAE}

Euroscaptor cf. orlovi Zemlemerova, Bannikova, Lebedev, Rozhnov, Abramov, 2016

Euroscaptor orlovi was first described from $\mathrm{Sa} \mathrm{Pa}$ District (Lao Cai Province, north-western Vietnam) (Zemlemerova et al., 2016). To date, in Vietnam, this species has been known to occur in Lao Cai Province only. Eight specimens were collected in the Cham Chu and Bac Me NRs during our surveys.

Our specimens have the same body size as those of E. orlovi and E. kuznetsovi and the tail shape as that of E. orlovi (Zemlemerova et al., 2016), while differ from other Euroscaptor species in the pelage colour and tooth structure. HB is $129.71(120.71-137.62) \mathrm{mm}$, TL is $14.82(8.93-19.28) \mathrm{mm}$, tail ratio is $7.4-18.3 \%$, and GL is $33.25(32.4-33.71) \mathrm{mm}$. Several specimens from Phu Luu (the Cham Chu NR) have a remarkable dark orange in neck and adjacent forearm by secretion
(Fig. 2). The molecular analysis showed that sequences from the studied specimens were at least $4.8 \%$ divergent from other Euroscaptor species based on the complete $c y t b$ gene (Tab. 4). Recent studies suggested that both E. orlovi and E. kuznetsovi inhabit high elevations (1900-2330 m and 700-1300 m a.s.l., respectively). However, our specimens were collected from lower elevations, $200 \mathrm{~m}$ (Phu Luu) to $700 \mathrm{~m}$ (Cao Duong) a.s.l. In our opinion, the taxonomic status and distribution of Euroscaptor moles in northern Vietnam are in need of re-evaluation. Bui Tuan Hai et al. (2019, 2020b), whose results were partly based on the collection from Tuyen Quang and Ha Giang provinces, hypothesized that Red River seems to be a biogeographic boundary between E. kuznetsovi and E. orlovi.

\section{ORDER CHIROPTERA Family PTEROPODIDAE}

\section{Cynopterus sphinx (Vahl, 1797)}

This is a medium-sized bat $(\mathrm{FA}=67.47-71.06 \mathrm{~mm}$; $\mathrm{GL}=29.96-32.44 \mathrm{~mm}$ ) with the short muzzle that is characterized by white margins on ears and pale wing digits. Sixteen individuals were captured using mist nets, of which 14 were from the Cham Chu NR and four from the Bac Me NR. They were collected from the orange plantation near the Phu Luu Commune and along a small stream in the secondary forest at the elevations of 300-600 m a.s.l. in the Bac Me NR. Some juvenile females were collected without moms in October during both fieldwork trips.

Taxonomic remarks: There are three species of the genus Cynopterus recorded from Vietnam: C. sphinx, C. brachyotis and C. horsfieldi (Kruskop, 2013), of which the former is most common. These species are similar in morphology and sometimes difficult to distinguish in the field. Yet, they can be easily separated by mitochondrial data (Bumrungsri \& Racey, 2005; Francis et al., 2010). Besides, C. sphinx can be distinguished from C. brachyotis by its size. For C. sphinx and C. horsfieldi, the shape and size of lower premolars are reported as a diagnostic feature (Lekagul \& McNeely, 1988; Kruskop, 2013; Dao Nhan Loi et al., 2017). To confirm a significant difference in their size, shape and a biogeographic variation of cranial characters, more samples are to be examined in future studies.

Macroglossus sobrinus Andersen, 1911

This is a small nectarivorous bat characterized by the elongated, slender muzzle and a very long tongue. Two females $(\mathrm{FA}=47.35-49.22 \mathrm{~mm} ; \mathrm{GL}=30.47-30.51 \mathrm{~mm})$ were captured by a mist net along a stream and near the orange plantation at the Cham Chu NR $\left(22.12667^{\circ} \mathrm{N}\right.$, $105.02972^{\circ} \mathrm{E}, 134 \mathrm{~m}$ a.s.1.).

Taxonomic remarks: The genus Macroglossus contains two species recorded from Vietnam. Morphologically, $M$. sobrinus is usually larger than $M$. minimus (Francis, 2019). They are distributed in lowland areas with mixed forest habitats, especially in the secondary plant formations with banana growth and mixed natural 
Table 3. Results of molecular identification based on cytb and COI fragments.

\begin{tabular}{|c|c|c|c|c|c|c|}
\hline \multirow{2}{*}{ Voucher No. } & \multirow{2}{*}{ Species } & \multirow{2}{*}{ Locality } & \multicolumn{2}{|c|}{ GenBank No. } & \multirow{2}{*}{$\begin{array}{l}\text { Simi- } \\
\text { larity }\end{array}$} & \multirow{2}{*}{ Reference } \\
\hline & & & cytb & $\mathrm{COI}$ & & \\
\hline NTS.2019.04.40 & Crocidura tanakae & Cao Duong & MW046275 & & $98.82 \%$ & Li et al., 2019 \\
\hline C.CHU.18.22 & Euroscaptor cf. orlovi & Phu Luu & MW046264 & & $94.21 \%$ & Zemlemerova et al., 2016 \\
\hline C.CHU.18.31 & Euroscaptor cf. orlovi & Phu Luu & MW046265 & & $94.67 \%$ & Zemlemerova et al., 2016 \\
\hline C.CHU.18.32 & Euroscaptor cf. orlovi & Phu Luu & MW046266 & & $94.39 \%$ & Zemlemerova et al., 2016 \\
\hline NTS.2019.04.38 & Euroscaptor cf. orlovi & Cao Duong & MW046267 & & $95.08 \%$ & Zemlemerova et al., 2016 \\
\hline NTS.2019.04.48 & Euroscaptor cf. orlovi & Cao Duong & MW046268 & & $94.61 \%$ & Zemlemerova et al., 2016 \\
\hline NTS.2019.04.50 & Euroscaptor cf. orlovi & Cao Duong & MW046269 & & $94.99 \%$ & Zemlemerova et al., 2016 \\
\hline NTS.2019.04.56 & Euroscaptor cf. orlovi & Cao Duong & MW046270 & & $94.47 \%$ & Zemlemerova et al., 2016 \\
\hline NTS.2019.04.57 & Euroscaptor cf. orlovi & Cao Duong & MW046271 & & $94.38 \%$ & Zemlemerova et al., 2016 \\
\hline C.CHU.18.11 & Cynopterus sphinx & Phu Luu & & MW039079 & $99.71 \%$ & Arai, 2019 \\
\hline C.CHU.18.14 & Cynopterus sphinx & Phu Luu & MW046263 & & $99.65 \%$ & Hassanin et al., 2020 \\
\hline NTS 2019.04.07 & Aseliscus dongbacanus & Cao Duong & & MW039080 & $99.26 \%$ & Arai, 2019 \\
\hline NTS 2019.04.08 & Aseliscus dongbacanus & Cao Duong & & MW039081 & $99.26 \%$ & Arai, 2019 \\
\hline NTS 2019.10.09 & Aseliscus dongbacanus & Cao Duong & & MW039082 & $99.26 \%$ & Arai, 2019 \\
\hline NTS.2019.10.32 & Rhinolophus pusillus & Lung Cang & MW046278 & & $99.06 \%$ & Shi et al., 2016 \\
\hline C.CHU.18.10 & Rhinolophus affinis & Phu Luu & & MW039078 & $98.29 \%$ & Mao et al., 2019 \\
\hline BM 2019.05.09 & Rhinolophus affinis & Khau Ca & MW046259 & & $98.29 \%$ & Mao et al., 2019 \\
\hline BM 2019.05.25 & Hipposideros armiger & Khau Ca & MW046261 & & $99.55 \%$ & Lin et al., 2014 \\
\hline BM.2019.05.07 & Hipposideros cf. larvatus & Khau Ca & MW046260 & & $99.29 \%$ & Li et al., 2007 \\
\hline NTS.2019.04.37 & Myotis chinensis & Cao Duong & MW046274 & & $98.12 \%$ & Guo et al., 2013 \\
\hline NTS 2019.10.45 & Callosciurus inornatus & Lung Cang & MW046276 & & $99.53 \%$ & Oshida et al., 2011 \\
\hline NTS.2019.04.58 & Rhizomys pruinosus & Cao Duong & MW046277 & & $99.29 \%$ & Steppan \& Schenk, 2017 \\
\hline C.CHU.18.01 & Chiromyscus thomasi & Phu Luu & MW046262 & & $99.35 \%$ & Balakirev et al., 2014 \\
\hline NTS 2019.10.37 & Chiromyscus langbianis & Cao Duong & MW046279 & & $98.65 \%$ & Pages et al., 2010 \\
\hline NTS 2019.04.31 & Niviventer fulvescens & Cao Duong & MW046272 & & $99.82 \%$ & Zhang et al., 2016 \\
\hline NTS 2019.10.38 & Niviventer fulvescens & Lung Cang & MW046273 & & $99.82 \%$ & Zhang et al., 2016 \\
\hline
\end{tabular}

Table 4. Pairwise genetic distance of Euroscaptor spp. based on a fragment of cytb gene.

\begin{tabular}{|l|l|c|c|c|c|c|c|c|c|c|}
\hline \multicolumn{2}{|l|}{} & 1 & 2 & 3 & 4 & 5 & 6 & 7 & 8 & 9 \\
\hline 1 & C.CHU.18.22 & - & & & & & & & & \\
\hline 2 & NTS.2019.04.38 & 0.840 & - & & & & & & & \\
\hline 3 & E. orlovi SIK0821 & 5.789 & 4.827 & - & & & & & & \\
\hline 4 & E. klossi SIK0673 & 9.123 & 8.648 & 7.982 & - & & & & & \\
\hline 5 & E. kuznetsovi SIK0865 & 6.316 & 6.047 & 5.614 & 7.895 & - & & & & \\
\hline 6 & E. longirostris KIZ0905172 & 8.860 & 9.010 & 7.807 & 8.596 & 7.105 & - & & & \\
\hline 7 & E. malayana SIK0550 & 8.421 & 8.169 & 7.807 & 8.596 & 7.105 & 8.158 & - & & \\
\hline 8 & $\begin{array}{l}\text { E. parvidens ngoclinhensis } \\
\text { SIK0858 }\end{array}$ & 13.772 & 13.191 & 13.070 & 13.246 & 12.544 & 12.456 & 13.509 & - & \\
\hline 9 & E. subanura SIK0938 & 16.316 & 15.761 & 15.877 & 15.702 & 14.737 & 15.439 & 14.825 & 15.526 & - \\
\hline
\end{tabular}



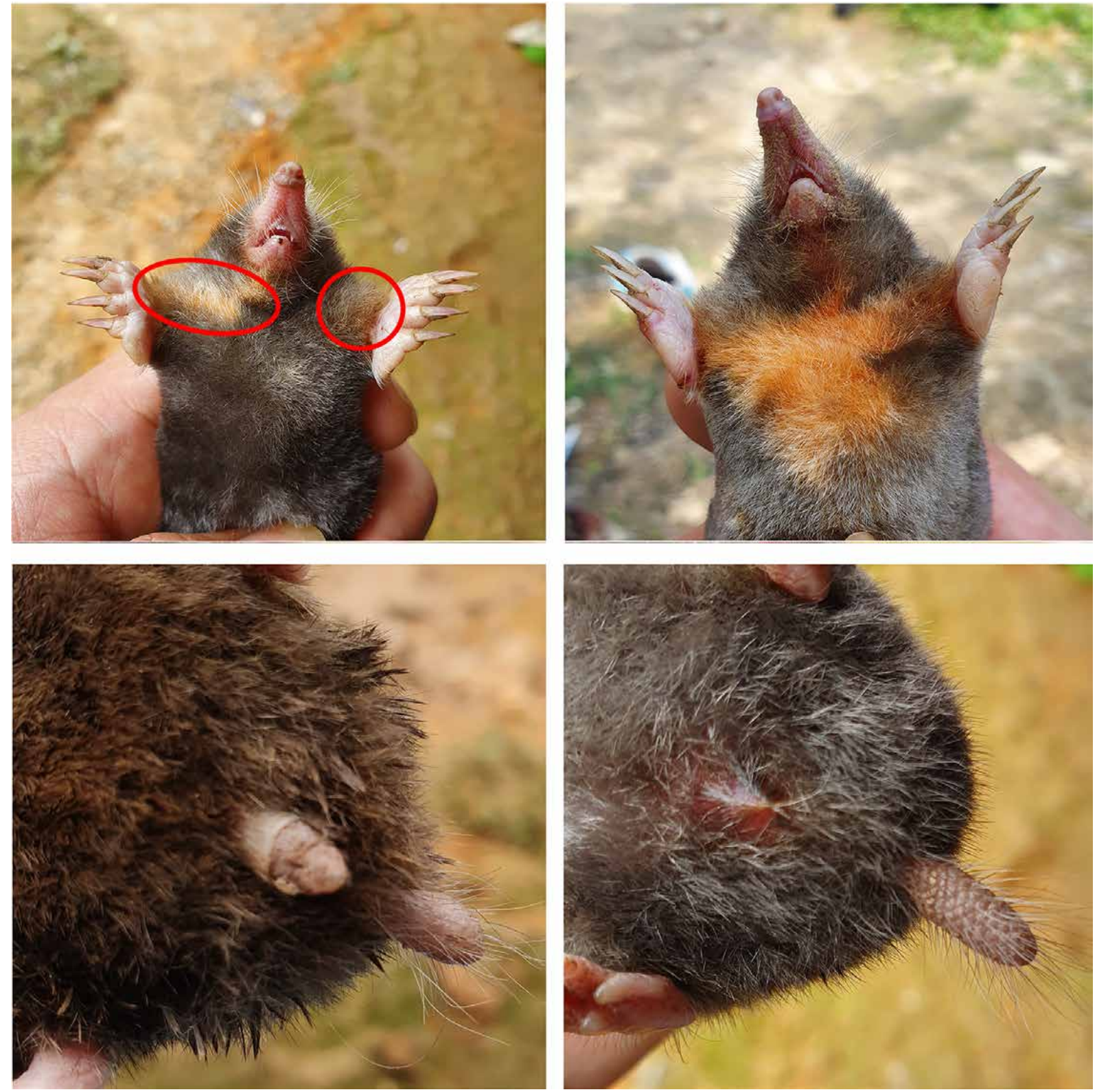

Fig. 2. Coloration of neck and adjacent forearms, and tail shape of two specimens of Euroscaptor cf. orlovi from the Cham Chu NR. Photographed by Bui Tuan Hai.

forest. In Vietnam, M. minimus has been recorded from two localities in southern Vietnam only, while M. sobrinus has been documented from all the northern, central and southern regions of the country. In Vietnam, the two species are distinguishable by the size, nostril shape and mandible symphyse (Kruskop, 2013; Hoang Trung Thanh et al., 2019), but are indistinguishable by their mitochondrial DNA (Francis et al., 2010; Abramov et al., 2018), probably due to an ancient interbreed event.

\section{Family RHINOLOPHIDAE}

Rhinolophus microglobosus Csorba, Jenkins, 1998

This is medium sized horseshoe bat, $\mathrm{FA}=44.89 \mathrm{~mm}$ (44.04-45.27 mm), GL=19.32 mm (18.61-20.10 mm), similar to $R$. stheno, but with a smaller skull size and a wider postorbital constriction (Kruskop, 2013; Francis, 2019).

Three females and two males were collected during the field surveys. All five individuals were harp-trapped 


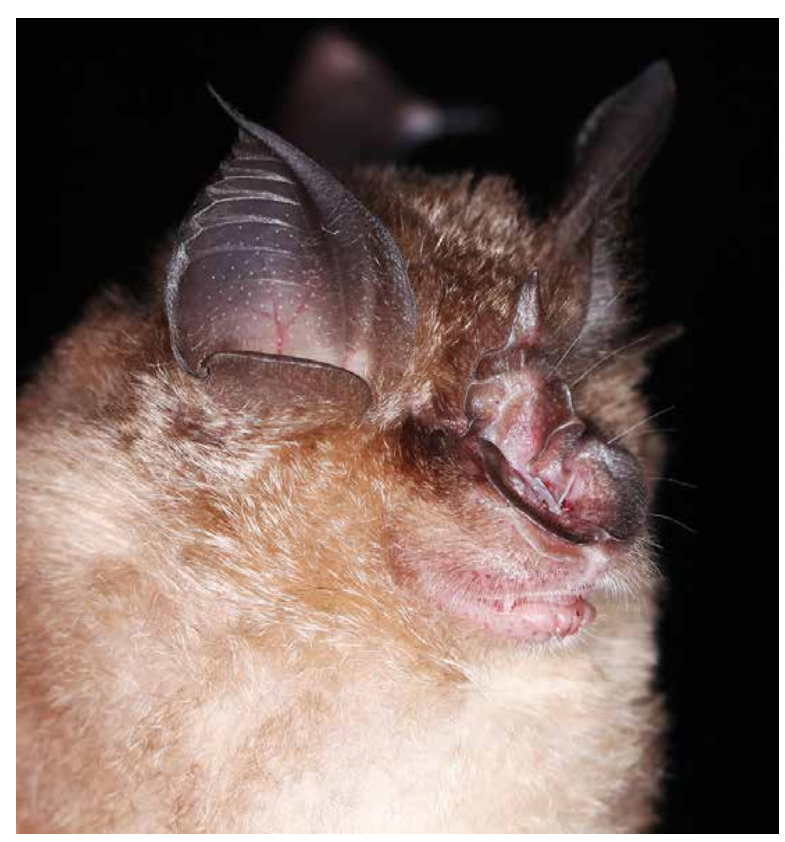

Fig. 3. Rhinolophus microglobosus. Photographed by Nguyen Truong Son.

at a cave's entrance near the Bac Me NR (Fig. 3). The colony size was estimated to be about 35-40 individuals.

Taxonomic remarks: This bat was originally described and for some time treated as a subspecies of R. stheno (Csorba \& Jenkins, 1998; Simmons, 2005). However, it has been demonstrated to be distinct based on generally smaller body and skull sizes and a higher call frequency, yet being found sympatrically with $R$. stheno s. str. (Soisook et al., 2008).

Rhinolophus pearsonii Horsfield, 1851

This is a medium to large horseshoe bat with FA 49-55 mm (Francis, 2019). Two females and one male were captured by a mist nest set up on small tracks near caves at the Phu Luu Hamlet $\left(22.2104^{\circ} \mathrm{N}, 105.0582^{\circ} \mathrm{E}\right.$, 220-230 $\mathrm{m}$ a.s.1.) in October, 2018 and the Cao Duong Hamlet $\left(22.2948^{\circ} \mathrm{N}, 104.9885^{\circ} \mathrm{E}, 664 \mathrm{~m}\right.$ a.s.l.) in April, 2019. The specimens have $\mathrm{FA}=53.82-54.66 \mathrm{~mm}, \mathrm{GL}=$ 24.43-25.89 mm.

Taxonomic remarks: This species has a wide range, occurring from Nepal, India, Bangladesh and Bhutan to southeast China, Laos, Myanmar, Thailand, Vietnam, and Peninsular Malaysia (Francis, 2019). In Vietnam, $R$. pearsonii is widespread across the country and quite common at middle elevations with limestone outcrops (Kruskop, 2013). Another species of the same species group in Vietnamese fauna is $R$. yunnanensis Dobson, 1872, which is morphologically similar but somewhat larger (Yoshiyuki, 1990; Srinivasulu et al., 2010). However, reliable records of the Yunnan horseshoe bat in Vietnam are still not known (Dang Ngoc Can et al., 2008; Kruskop, 2013). At the same time, the high genetic diversity within $R$. pearsonii suggests its taxonomic heterogeneity (Francis et al., 2010). Therefore, the taxonomy of this species group, including Vietnamese populations, requires further study.

\section{Rhinolophus pusillus Temminck, 1834}

This small-sized bat is widespread in Vietnam (Kruskop, 2013). One male was captured by a harp trap at a cave in the mountainous forest habitat near the Bac $\operatorname{Me~NR}(F A=36.91 \mathrm{~mm}, \mathrm{GL}=13.57 \mathrm{~mm})$, where some other species were also observed, such as Hipposideros cf. larvatus and Aselliscus dongbacanus.

Taxonomic remarks: This species is widespread in SE Asia, southern and south-western China, being recorded from 200-1370 m a.s.l. (Fukui, 2019). Yet, the taxonomy of pygmy horseshoe bats from the "pusillus" species complex remains problematic (Abramov \& Kruskop, 2012). In Vietnam, four species of the "pusillus" species group have been reported: viz., $R$. subbadius, $R$. pusillus, $R$. lepidus and $R$. acuminatus (Dang Ngoc Can et al., 2008; Kruskop, 2013). Of these, $R$. acuminatus is well distinguishable by the relatively large size, while identification of other species may cause certain problems (e.g. Abramov \& Kruskop, 2012). R. pusillus is supposed to be a common species that is distributed in both primary and secondary forest habitats across the country, while $R$. lepidus is known mainly from the Central Highlands and southern Vietnam (Wu et al., 2012; Kruskop, 2013; Hoang Trung Thanh, 2018). In Vietnam, in order to clarify the taxonomic status of local forms of $R$. pusillus and $R$. lepidus further sampling is needed.

\section{Rhinolophus rex G.M. Allen 1923}

This is a medium-sized bat (FA $=53-57 \mathrm{~mm})$ with enormous ears (Francis, 2019). One male (FA = $55.36 \mathrm{~mm}, \mathrm{GL}=22.13 \mathrm{~mm}$ ) and one pregnant female $(\mathrm{FA}=54.75 \mathrm{~mm}, \mathrm{GL}=21.40 \mathrm{~mm})$ were collected by a harp trap near a cave in the Cham Chu NR $\left(22.2948^{\circ} \mathrm{N}\right.$, 104.9885 E, 664 m a.s.1.) in April, 2019 (Fig. 4).

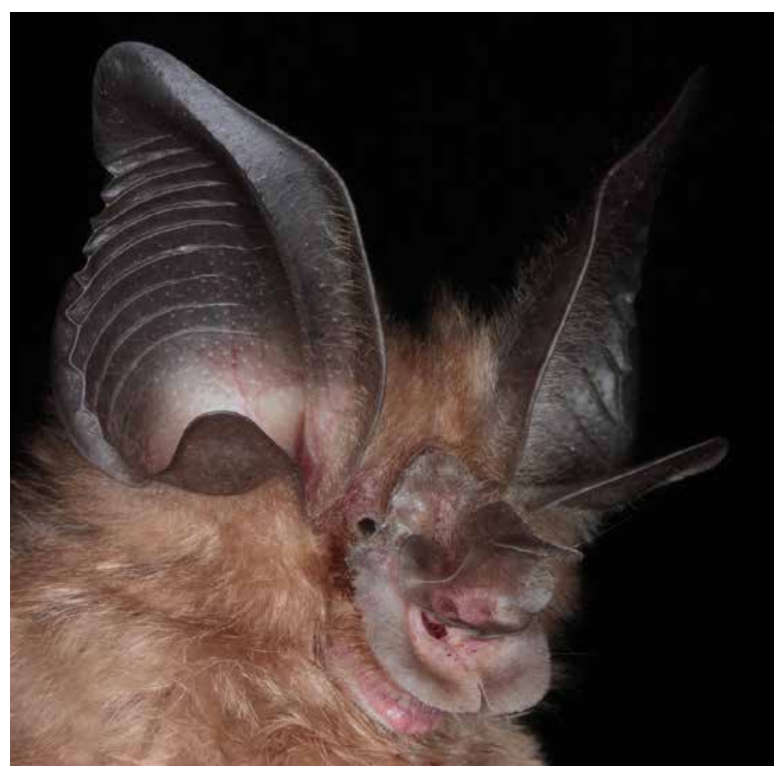

Fig. 4. Rhinolophus rex. Photographed by Nguyen Truong Son. 
Rhinolophus thomasi Andersen, 1905

We collected three individuals (two males from the Cham Chu NR, one female from the Bac Me NR) and identified them on the basis of their morphology with $\mathrm{FA}=45.56 \mathrm{~mm}, \mathrm{GL}=46.26-48.06 \mathrm{~mm}$. The obtained fragment of $c y t b$ was compared with the sequences available from GenBank using the BLAST tool and the sequence is $97.7 \%$ similar to $R$. sinicus (GenBank accession no. KP257597, Sun et al., 2016), 99.1\% to R. thomasi (GenBank accession no. EU434943, Sun et al., 2009), and $98.3 \%$ to $R$. affinis (GenBank accession no. MK976912, Mao et al., 2019).

Taxonomic remarks: Despite Dang Ngoc Can et al. (2008) arguing that this is a widespread Vietnamese species, Kruskop (2013) demonstrated that the species remains poorly known and occurs in the Phong Nha-Ke Bang NP only. In its natural history, the species is similar to $R$. sinicus. Nguyen Truong Son et al. (2010, 2011), Dang Huy Phuong \& Nguyen Truong Son (2011), and Dang Huy Phuong et al. (2013) suggested that the species is mostly recorded from limestone areas. Recently, there is no unambiguous decision on a species affiliation of this taxon in Vietnam.

\section{Family HIPPOSIDERIDAE}

Aselliscus dongbacanus Vuong, Csorba, Görföl, Arai, Nguyen, Hoang, Hasanin, 2015

This is a small leaf-nosed bat (mean FA $=42.25 \mathrm{~mm}$, mean $\mathrm{GL}=15.39 \mathrm{~mm}$ ) that in its size and external morphology is very close to the widespread $A$. stoliczkanus (Vuong Tan Tu et al., 2015), from which it differs primarily in the longer canines. Our specimens were captured at limestone caves in both Bac Me and Cham Chu NRs. Forty individuals were caught by a harp trap at the sites surrounded by forest in the Bac Me area $\left(22.8512^{\circ} \mathrm{N}, 105.1796^{\circ} \mathrm{E}, 737 \mathrm{~m}\right.$ a.s.1.) and in Cham Chu $\left(22.2948^{\circ} \mathrm{N}, 104.9885^{\circ} \mathrm{E}, 664 \mathrm{~m}\right.$ a.s.1.). This species was found together with other leaf-nosed bats, Hipposideros armiger and $H$. cf. larvatus. According to our estimation, a species' colony size in the surveyed caves was 300 to 400 individuals. This species was described in 2015 from the limestone area of the Ba Be NP in Bac Kan Province, north-eastern Vietnam and was also reported from Tuyen Quang, Ha Giang and Cao Bang Provinces (Vuong Tan Tu et al., 2015). The closely related $A$. stoliczkanus has been recorded from north-western and central Vietnam and Laos, Thailand, Myanmar (Francis, 2019); the ranges of two species are likely to be separated by the Red River valley.

Hipposideros armiger (Hodgson, 1835)

It is the largest Asian Hipposideros species with FA up to $98.9 \mathrm{~mm}$ and GL up to $32.01 \mathrm{~mm}$ (Vu Dinh Thong et al., 2012). Morphologically, it is highly similar to the recently described $H$. griffini (see Vu Dinh Thong et al., 2012), from which it mainly differs in larger skull measurements. Fourteen individuals $(\mathrm{FA}=86.57-96.58 \mathrm{~mm}$, $\mathrm{GL}=31.11-32.91 \mathrm{~mm}$ ) were collected from caves in the Bac Me and Cham Chu NRs, where other bat species, such as $A$. dongbacanus and $H$. cf. larvatus, were also found. Few individuals were also collected using mist nets outside the caves and other study sites. In the Bac Me NR, they roosted in high and large cavities on the ceiling of a limestone cave. The colony size was estimated to be of some 200 individuals. The colony size in the Cham Chu NR was smaller. Some pregnant females were collected in May in the Bac Me NR.

Taxonomic remarks: Analysis of complete $c y t b$ gene and partial D-loop have shown that $H$. armiger differs from the closely related $H$. griffini by $5.3-5.4 \%$ (Vu Dinh Thong et al., 2012). However, recent results in nuclear genes have shown no significant deviation between these species (Yusefovich et al., 2020). This result together with uncertain morphological difference and unclear border of distribution areas of both species suggests the need for the further and more wide-scale studies.

Hipposideros cf. larvatus (Horsfield, 1823)

Thirty-five individuals of this medium-size leafnosed bat were captured (FA $=55.10-61.50 \mathrm{~mm}, \mathrm{GL}=$ 21.91-23.39 mm), composing about $28.7 \%$ of all bats captures during the field work in both sites. These bats were observed in larger limestone caves with high ceilings. The colony in the Bac Me NR was estimated to be 100-200 individuals. They concentrated in small groups in different positions and co-occupied the cave with other species, including $H$. armiger, A. dongbacanus and $H$. gentilis. This species alongside with A. dongbacanus was found to be the most abundant bat in this area, occurring almost in all studied habitats. Some collected males captured in the Bac Me NR in October possessed a well-developed frontal gland behind the posterior noseleaf (Fig. 5).

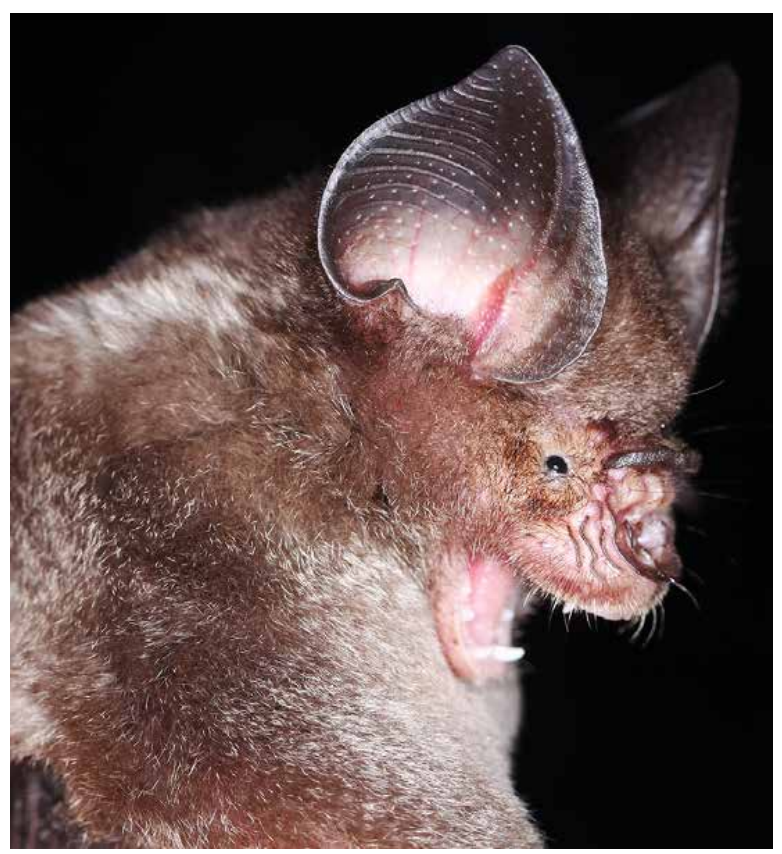

Fig. 5. Hipposideros cf. larvatus. Photographed by Nguyen Truong Son. 
Taxonomic remarks: The H. larvatus species complex has a vast distribution across SE Asia (Francis, 2019) and, in particular, throughout Vietnam (Kruskop, 2013). The taxonomic structure and species delimitations within this complex are highly tangled and insufficiently studied (Thabah et al., 2006; Kruskop, 2015). In the latter study, it was shown that there are at least four species in this complex in the Vietnam, and most probably none of them belongs to "true" H. larvatus. A smaller form inhabiting northern Vietnam differs genetically from $H$. larvatus from southern Thailand, as well as from $H$. grandis, and sometimes is referred to as $H$. cf. poutensis (Yusefovich et al., 2020). H. poutensis was described from Hainan Island (Allen, 2006); comparative material from there is needed to clarify the matter. Until such a comparison is undertaken, we have designated the studied morphotype as $H$. cf. larvatus.

\section{Hipposideros gentilis K. Andersen, 1918}

This is a small sized bat with FA about $40.69 \mathrm{~mm}$ $(39.2-42.17 \mathrm{~mm})$ and large rounded ears. Two specimens were captured in the Bac Me NR by mist nets, one in a karst cave in May and another, a juvenile female in October 2019.

Taxonomic remarks: This species was previously considered within $H$. pomona. However, it was shown that specimens of $H$. pomona from the type locality (SW India) and those from the remaining range differ significantly in morphology, and the two forms should be regarded as different species (Srinivasulu \& Srinivasulu, 2018). “H. gentilis K. Andersen, 1918” represents the valid name for the second form. Its intraspecies structure is complicated, containing few highly divergent mitochondrial lineages of an uncertain taxonomic status

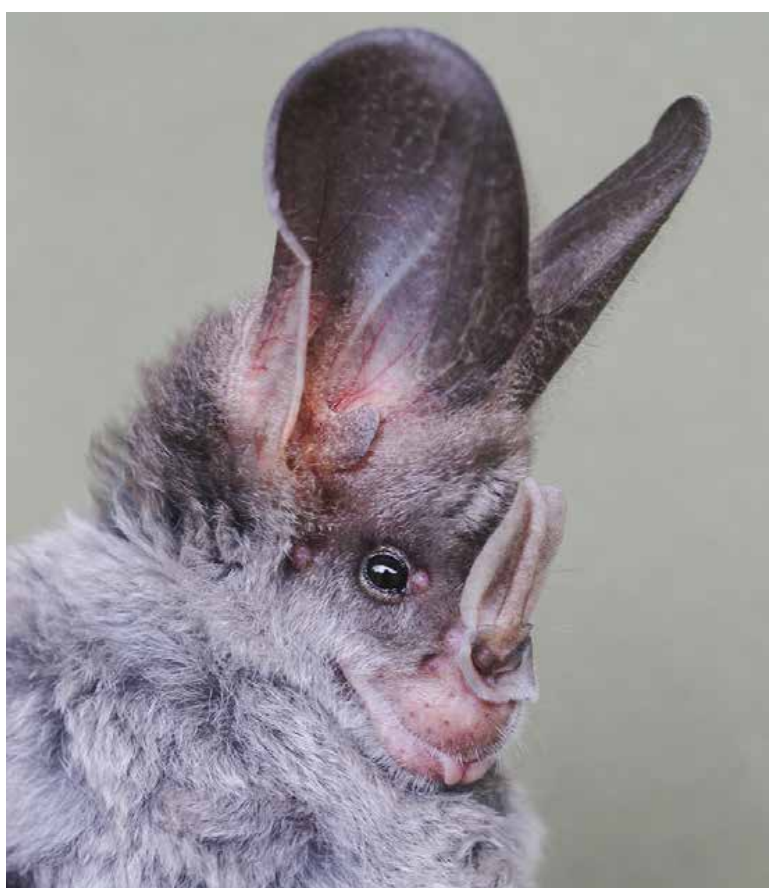

Fig. 6. Lyroderma lyra. Photographed by Ly Ngoc Tu.
(Francis et al., 2010; Zhao et al., 2015). However, it was shown that all these lineages at least form a monophyletic group (Yusefovich et al., 2020).

\section{Family MEGADERMATIDAE}

\section{Lyroderma lyra E. Geoffroy, 1810}

Until recently, this large species of the false vampire bats was considered within the genus Megaderma. However, both genetics and morphology support its distinct generic status (Soisook et al., 2015).

During the field survey, four females were captured in Loong Booc Cave $\left(22.2296^{\circ} \mathrm{N}, 105.0489^{\circ} \mathrm{E}, 293 \mathrm{~m}\right.$ a.s.1.) at Cham Chu NR with $\mathrm{FA}=68.8-71.76 \mathrm{~mm}, \mathrm{GL}=$ 29.64-31.14 mm (Fig. 6).

\section{Family VESPERTILIONIDAE}

Myotis chinensis (Tomes, 1857)

It is the largest Myotis species in SE Asia (Francis, 2019). In Vietnam, records include the Hoang Lien NP (Lao Cai Province), the Ba Be NP (Bac Kan Province), the Na Hang NR (Tuyen Quang Province), the Huu Lien NR (Lang Son Province), the Cuc Phuong NP (Ninh Binh Province), the Xuan Son NP (Phu Tho Province), the $\mathrm{Pu}$ Mat NP (Nghe An Province) and the Phong Nha-Ke Bang NP (Quang Binh Province) (Bates et al., 1999; Hendrichsen et al., 2001; Nguyen Truong Son et al., 2002; Dang Ngoc Can et al., 2008). Despite having a wide range, the population status of this species in Vietnam has not been accurately assessed.

During the field survey, an adult male (FA $=$ $66.26 \mathrm{~mm}, \mathrm{GL}=24.17 \mathrm{~mm}$ ) was collected (Fig. 7). The animal was captured by a mist net set up across a stream nearby a cave $\left(22.2948^{\circ} \mathrm{N}, 104.9883^{\circ} \mathrm{E}, 664 \mathrm{~m}\right.$ a.s.l.) at the late night. To date, the species in northern and central Vietnam has only been recorded from near cave entrances in limestone habitats with the presence of rivers or streams (Bates et al., 1999, 2001; present paper).

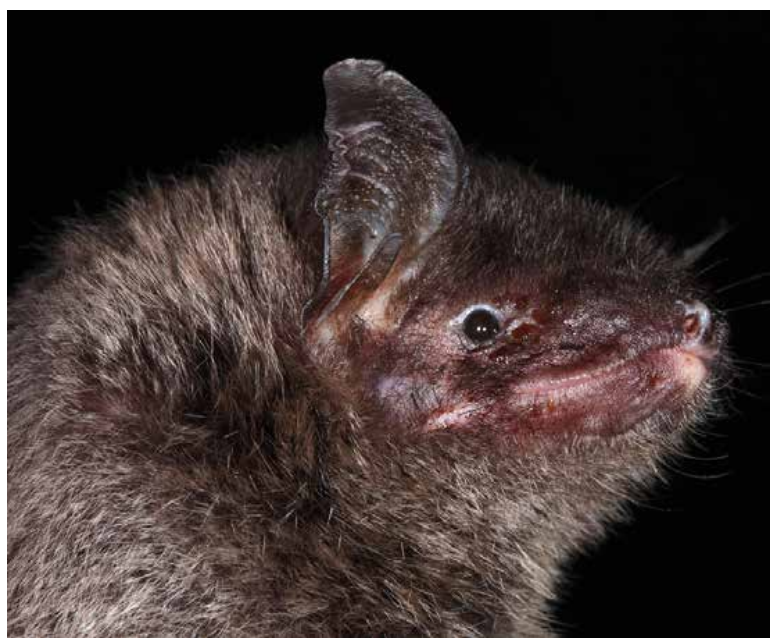

Fig. 7. Myotis chinensis. Photographed by Nguyen Truong Son. 


\section{ORDER RODENTIA \\ Family SPALACIDAE}

\section{Rhizomys pruinosus (Blyth, 1851)}

The hoary bamboo rat is a common and widespread species in Vietnam (Francis, 2019; Dang Huy Huynh et al., 2008). Its preferred habitat is a hilly bamboo forest mixed up with scrub and grass (Lunde \& Nguyen Truong Son, 2001). This species is often hunted for food by local people (Aplin \& Molur, 2016).

During our surveys, one specimen of $R$. pruinosus was collected by the local trapper in the Cham Chu NR. The external body measurements of this species are as follows: $\mathrm{BW}=1300 \mathrm{~g}, \mathrm{HB}=320 \mathrm{~mm}, \mathrm{TL}=140 \mathrm{~mm}$, $\mathrm{HF}=57.54 \mathrm{~mm}$, and $\mathrm{E}=22.82 \mathrm{~mm}$. Based the external morphology data by Francis (2019), a significant difference in the tail length of the studied specimen $(140 \mathrm{~mm}$ vs. 100-120 mm) has been recorded. Besides, its fur colour is greyish brown, with many long guard hairs, and more specifically with a white blaze on the forehead (from the top of the nose to the forehead). The cheek fur is lighter (Fig. 8). However, a molecular analysis shows that the specimen indeed belongs to R. pruinosus (Tab. 3).

\section{Family SCIURIDAE}

Belomys pearsonii (Gray, 1842)

This widespread species in distributed throughout northern to southern Vietnam, such as Ha Giang, Lao Cai, Quang Binh, Dong Nai, Ba Ria-Vung Tau Provinces (Dang Ngoc Can et al., 2008; Oshida et al., 2015). This species can only be found in the areas of high-quality forests with tall canopies that allow animals to hover. But currently, the information about the records and distribution of this species are still deficient due to a relatively small number of individuals in nature.

One adult female was caught by using a local trap in a limestone forest habitat of the Bac Me NR, $22.85278^{\circ} \mathrm{N}$, $105.15417^{\circ} \mathrm{E}, 630 \mathrm{~m}$ a.s.1.) in 27 May 2019. This is a small flying squirrel with $\mathrm{BW}=200 \mathrm{~g} ; \mathrm{HB}=185 \mathrm{~mm}$, $\mathrm{TL}=165 \mathrm{~mm}, \mathrm{HF}=27.75 \mathrm{~mm}, \mathrm{HF}=34.73 \mathrm{~mm}$, and $\mathrm{E}=20.99 \mathrm{~mm}$.

Taxonomic remarks: Thorington et al. (2012) recognized four subspecies of B. pearsonii: pearsonii, blandus, kaleensis, and trichotis. Based on the specimens from Vietnam, Oshida et al. (2015) showed a significant genetic variation within $B$. pearsonii, with a pairwise distance of the complete $c y t b$ sequences being greater than $11 \%$ among the populations from northern and central Vietnam. A further study on the external, craniodental and bacular morphology of the Belomys species is needed to identify clear diagnostic characters.

\section{Family MURIDAE}

\section{Chiromyscus thomasi}

Balakirev, Abramov, Rozhnov, 2014

C. thomasi was suggested to occur from north-western (Son La, Lao Cai Provinces) to central Vietnam (Kon Tum and Nghe An Provinces) (Balakirev et al., 2014).

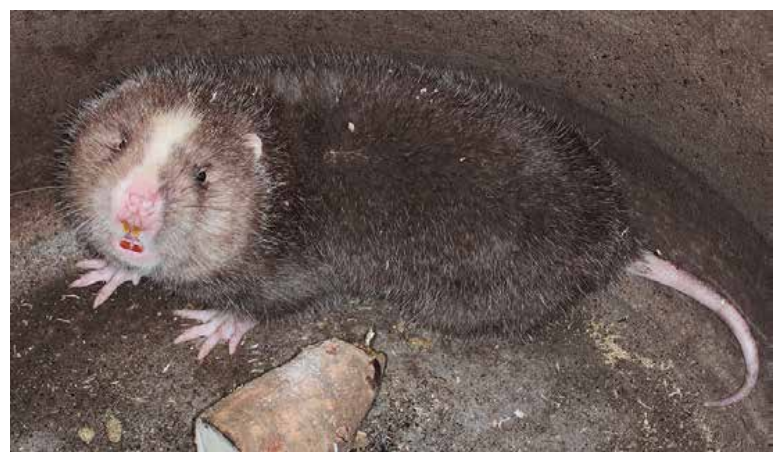

Fig. 8. Rhizomys pruinosus from the Cham Chu NR. Photographed by Nguyen Truong Son.

This species was recently found in Dien Bien Province in 2019 (the specimen deposited in the Institute of Ecology and Biological Resource, Vietnam Academy of Science and Technology).

During the present survey, a single female was collected in the Cham Chu NR at $255 \mathrm{~m}$ a.s.l. HB length of this specimen is $180 \mathrm{~mm}, \mathrm{TL}=250 \mathrm{~mm}$. Balakirev et al. (2014) reported this species to have $\mathrm{HB}=145-180 \mathrm{~mm}$ and a relatively short tail (200-231 mm). GL of the Cham Chu specimen is $44.58 \mathrm{~mm}$ against $41-43 \mathrm{~mm}$ in specimens from Son La Province (Balakirev et al., 2014). Genetically, this specimen is close to the holotype of C. thomasi from Son La (Tab. 3).

The find of this species in the Cham Chu NR enlarges the known species range in northern Vietnam. Thus, this species occurs on both sides of Red River.

Chiromyscus langbianis (Robinson, Kloss, 1922)

C. langbianis is a common species distributed throughout Vietnam (Dang Ngoc Can et al., 2008). We collected five specimens during the field surveys, one from the Cham Chu NR and four from the Bac Me NR. The specimens were captured by cage traps baited by cassava. This rat has a medium size $(\mathrm{HB}=140-190 \mathrm{~mm})$ with a long monochrome black tail ( $\mathrm{TL}=180-220 \mathrm{~mm})$. The specimen NTS 2019.10.37 from Ha Giang Province, which is in the Niviventer clade (Fig. 9), was identified genetically as $C$. langbianis.

Taxonomic remarks: Niviventer-Chiromyscus s. lato is a complex group. A taxonomic status of the Lang Bian rat is still controversial. Balakirev et al. (2014) placed Niviventer langbianis to the genus Chiromyscus based on molecular data. In our tree, the monophyly of Niviventer, including C. langbianis, is not supported with high confidence (Bayesian posterior probability, $\mathrm{PP}=71 \%$ ). However, independent clades within the genus are significantly corroborated ( $\mathrm{PP} \geq 98 \%)$ as is the genus Chiromyscus $(\mathrm{PP}=100 \%)$. More data, both from mitochondrial and nuclear genes, are needed to clarify the relationships in this group.

Niviventer fulvescens (Gray, 1874)

$N$. fulvescens is a widespread and common species in SE Asia (Balakirev et al., 2011; Francis, 2019). This 


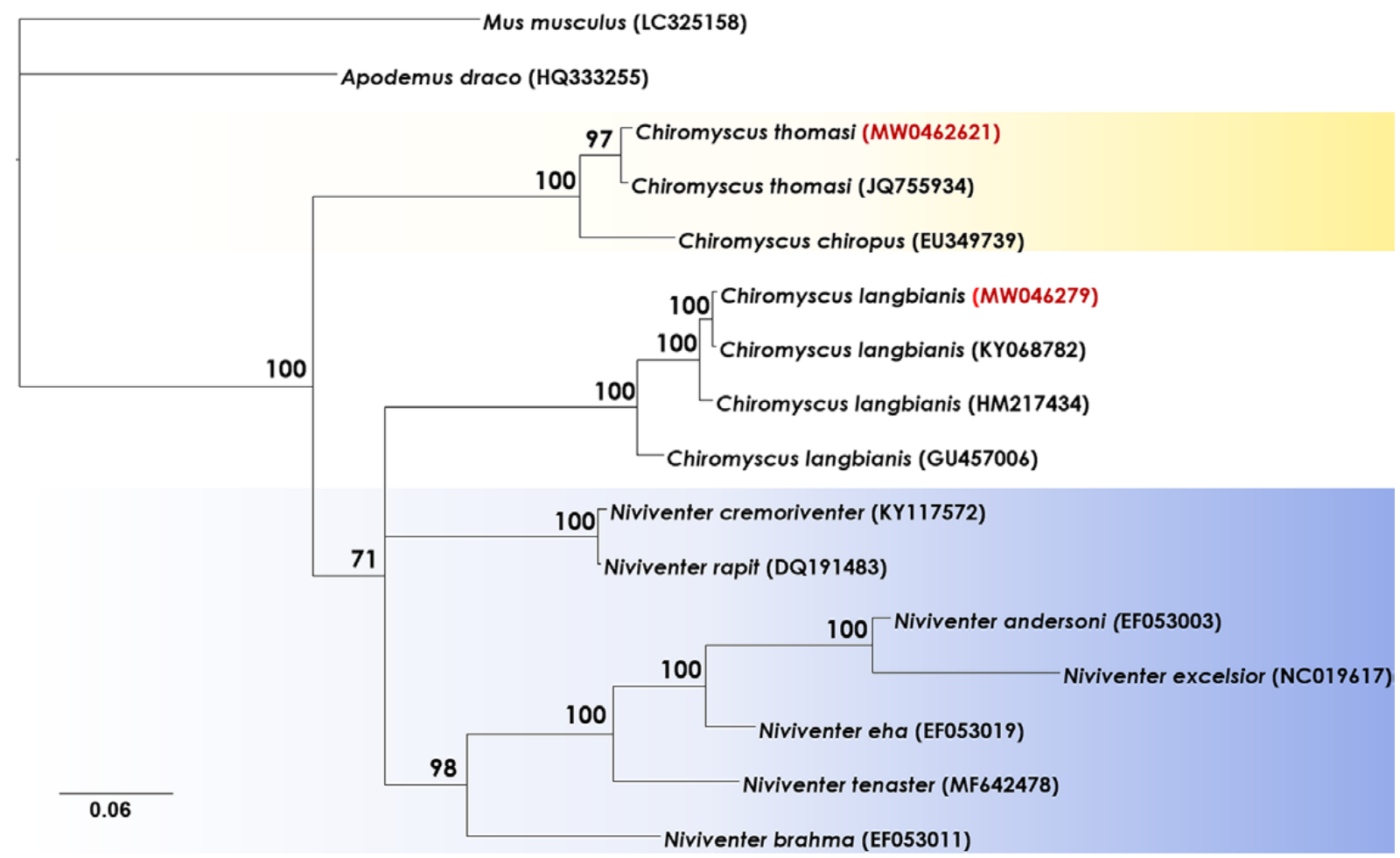

Fig. 9. The phylogenetic relationships in Niviventer-Chiromyscus, as reconstructed by the MrBayes based on cytb and partial tRNA-Thr data using GTR $+\mathrm{I}+\mathrm{G}$ model. Numbers above branches correspond to Bayesian posterior probabilities.

species is usually caught by cage-traps set up on trees along streams.

During the field survey, we collected three specimens of this species. Among them, one was subadult and could not be identified with confidence. We decided to use the DNA barcoding approach to determine its taxonomic status. Our sequence data confirmed that the specimen indeed belongs to $N$. fulvescens (Tab. 3).

\section{Conclusion}

Based on the results of our field surveys, the studied sites of the Cham Chu and Bac Me NRs account for one Scandentia species, four Eulipotyphla species, 14 Chiroptera species and 17 Rodentia species. However, many species documented in Tuyen Quang and Ha Giang by Nguyen Truong Son et al. (2011) could not be confirmed during our surveys, including Blarinella griselda, Chodsigoa caovansunga, Chodsigoa parca, Scaptonyx fusicaudus, Mogera latouchei, Hipposideros gentilis, Leopoldamys spp.

Our study shows a greater number of species in the surveyed sites than that recorded from the Huu Lien NR in Lang Son Province (21 species) (Lunde et al., 2007). However, the number of bat species is lower than that documented in the Ba Be NP (27 species) and the Na Hang NR (45 species) (Nguyen Truong Son \& Vu Dinh Thong, 2008). These regions share some common species: viz., Suncus murinus, Cynopterus sphinx,
Rhinolophus pearsonii, $R$. pusillus, $R$. microglobosus, Hipposideros armiger, $H$. cf. larvatus, Aselliscus dongbacanus, Rhizomys pruinosus, Callosciurus erythraeus, C. inornatus and Rattus andamanensis.

We were able to capture only one individual of Belomys pearsonii in the Khau Ca Forest. This flying squirrel is regarded as an indicator of a forest quality (Kato et al., 2011). IUCN (2020) listed it as Data Deficient, whereas the Vietnam Red Data Book (2007) accessed it as a Critically Endangered species.

Based on both molecular and morphological evidence, the new records of Aselliscus dongbacanus and Chiromyscus thomasi in north-eastern Vietnam have been confirmed. Besides, although external characters and skull morphology of all the collected mole specimens being similar to those of Euroscaptor orlovi, they are significantly different genetically. Therefore, future studies on the mole population should be conducted to clarify the taxonomic status of the studied population.

Some species are considered rare because the number of specimens encountered were fewer than 10, although the survey efforts were high. The total survey effort for the bat was $4374 \mathrm{~m}^{2} \mathrm{n} / \mathrm{h}$ mist nest and $675 \mathrm{~m}^{2} \mathrm{n} / \mathrm{h}$ harp trap. However, we could only collect single specimens of several bat species, including Rhinolophus pusillus, R. affinis and Myotis chinensis. The total survey effort for rodents is 981 trap nights, but for some species, only a single specimen was collected: e.g., Berylmys bowersi and Chiropodomys gliroides. Moreover, several 
common species did not yield many specimens: viz., Callosciurus inornatus (two specimens collected in the Bac Me NR), Rhizomys pruinosus (only one specimen from Cao Duong, the Cham Chu NR). We did not record any information on the mammal occurrence in the areas close to anthropogenic places, rice lands and orange plantations. However, we observed many individuals of these species in local houses. The situation suggests that the surveyed sites are heavily impacted by human activities, such as orange production, agricultural expansion, forest loss, mining, and especially by a high level of poaching. The species considered in this study warrant further investigation to verify their conservation status and assess possible anthropogenic threats.

Based on the present survey, the dominant mammal groups in terms of species diversity are Chiroptera (40\%) and Rodentia (45.7\%). However, the number of bat species is much lower, as compared to the earlier study conducted in the same region (16 vs. 35) (Nguyen Truong Son et al., 2011). We have also documented a couple of abundant species, such as Aselliscus dongbacanus (40 of 176 specimens) and Hipposideros cf. larvatus (37 of 176 specimens). Other common species include Suncus murinus, Aselliscus dongbacanus, Hipposideros armiger, $H$. cf. larvatus, Callosciurus erythraeus, C. inornatus and Rhizomys pruinosus.

ACKNOWLEDGMENTS. We are grateful to the directorates of the Cham Chu and Bac Me NRs for the support of our field work and issuing relevant permits. We are obliged to Dmitri V. Logunov (Manchester Museum, UK) for improving the English of the final draft. This project was funded by the NEF Bio-ecological Nature Conservation Project in Mountainous Region of Northern Vietnam, VAST-JSPS (QTJP01.02/18-20) and was in part supported by the Ministry of Science and Higher Education of the Russian Federation (project AAAA-A19-119082990107-3).

\section{References}

Abramov A.V., Bannikova A.A., Lebedev V.S. \& Rozhnov V.V. 2017. Revision of Chimarrogale (Lipotyphla: Soricidae) from Vietnam with comments on taxonomy and biogeography of Asiatic water shrews // Zootaxa. Vol.4232. No.2. P.216-230.

Abramov A.V. \& Kruskop S.V. 2012. The mammal fauna of Cat Ba Island, northern Vietnam // Russian Journal of Theriology. Vol.11. No.1. P.57-72.

Abramov A.V., Kruskop S.V. \& Shchinov A.V. 2018. Mammals of Con Son Island, southern Vietnam // Russian Journal of Theriology. Vol.17. No.1. P.1-16.

Allen J.A. 1906. Mammals from the Island of Hainan, China // Bulletin of the American Museum of Natural History. Vol.22. P.463-490.

Aplin K. \& Molur S. 2016. Rhizomys pruinosus. The IUCN Red List of Threatened Species 2016. e.T19645A115152385.

Arai S., Kikuchi F., Bawm S., Nguyen Truong Son, Lin K.S., Vuong Tan Tu, Aoki K., Tsuchiya K., Tanaka-Taya K., Morikawa S., Oishi K. \& Yanagihara R. 2019. Molecular phylogeny of mobatviruses (Hantaviridae) in Myanmar and Vietnam // Viruses. Vol.11. No.3. e.228.

Balakirev A.E., Abramov A.V. \& Rozhnov V.V. 2011. Taxonomic revision of Niviventer (Rodentia, Muridae) from Vietnam: a morphological and molecular approach // Russian Journal of Theriology. Vol.10. No.1. P.1-26.

Balakirev A.E., Abramov A.V. \& Rozhnov V.V. 2014. Phylogenetic relationships in the Niviventer-Chiromyscus complex (Rodentia, Muridae) inferred from molecular data, with description of a new species // ZooKeys. Vol.451. P.109-136.

Bannikova A.A., Abramov A.V., Borisenko A.V., Lebedev V.S. \& Rozhnov V.V. 2011. Mitochondrial diversity of the whitetoothed shrews (Mammalia, Eulipotyphla, Crocidura) in Vietnam // Zootaxa. Vol.2812. No.1. P.1-20.

Bates P.J.J., Hendrichsen D.K., Walston J.L. \& Hayes B. 1999. A review of the mouse-eared bats (Chiroptera: Vespertilionidae: Myotis) from Vietnam with significant new records // Acta Chiropterologica. Vol.1. No.1. P.47-74.

Bates P.J., Nwe T., Swe K.M. \& Bu S.S.H. 2001. Further new records of bats from Myanmar (Burma), including Craseonycteris thonglongyai Hill, 1974 (Chiroptera: Craseonycteridae) // Acta Chiropterologica. Vol.3. No.1. P.33-41.

Brook S., de Groot P.V.C., Mahood S. \& Long B. 2011. Extinction of the Javan rhinoceros (Rhinoceros sondaicus) from Vietnam. WWF Report. Hanoi: WWF Vietnam. $44 \mathrm{p}$. Brook S.M., de Groot P.V.C., Scott C., Boag P., Long B., Ley R.E., Reischer G.H., Williams C., Mahood S.P., Tran Minh Hien \& Polet G. 2012. Integrated and novel survey methods for rhinoceros populations confirm the extinction of Rhinoceros sondaicus annamiticus from Vietnam // Biological Conservation. Vol.155. P.59-67.

Bui Tuan Hai, Ly Ngoc Tu, Vu Thuy Duong, Le Duc Minh, Nguyen Thi Tham \& Nguyen Truong Son. 2019. Supplementary data of insectivores (Mammalia, Eulipotyphla) in Vietnam // Journal of Biology. Vol.41. No.2se1-2se2. P.393-407.

Bui Tuan Hai, Masaharu M., Ninh Thi Hoa \& Le Xuan Canh. 2020a. A revision of the geographical distributions of the Southeast Asian shrews (Crocidura dracula \& C. fuligino$s a$ ) based on new collection in Vietnam // Proceeding of the $4^{\text {th }}$ National Scientific Conference on Biological Research and Teaching in Vietnam. Hanoi. P.3-10.

Bui Tuan Hai, Masaharu M., Kawada S., Abramov A.V. \& Nguyen Truong Son. 2020b. Skull variation in Asian moles of the genus Euroscaptor (Eulipotyphla: Talpidae) in Vietnam // Mammal Study. Vol.45. No.4. P.265-280.

Bumrungsri S. \& Racey P.A. 2005. Field discrimination between lesser short-nosed fruit bat (Cynoptera brachyotis Muller, 1938) and greater short-nosed fruit bat (Sphinx Vahl, 1797) (Chiroptera: Pteropodidae) in South East Thailand // History Bulletin of The Siam Society. Vol.53. P.111-121.

Clements R., Sodhi N.S., Schilthuizen M. \& Ng P.K. 2006. Limestone karsts of Southeast Asia: imperiled arks of biodiversity // Bioscience. Vol.56. No.9. P.733-742.

Csorba G., Ujhelyi P. \& Thomas N. 2003. Horseshoe Bats of the World (Chiroptera: Rhinolophidae). Bishop's Castle, Shropshire: Alana Books. 160 p.

Csorba G. \& Jenkins P. 1998. First records and a new subspecies of Rhinolophus stheno (Chiroptera, Rhinolophidae) from 
Vietnam // Bulletin of Natural History Museum, Zoology Series. Vol.64. P.207-211.

Dang Huy Huynh, Cao Van Sung, Le Xuan Canh, Pham Trong Anh, Nguyen Xuan Dang, Hoang Minh Khien \& Nguyen Minh Tam. 2008. [Fauna of Vietnam. Vol.25. Mammalia: Primates, Carnivora, Artiodactyla, Perissodactyla, Rodentia]. Hanoi: Science and Technics Publishing House. 363 p. [in Vietnamese].

Dang Huy Phuong \& Nguyen Truong Son. 2011. [Value of mammal species of Northwest Vietnam] // Proceedings of the $4^{\text {th }}$ National Scientific Conference on Ecological and Biological Resources, Hanoi. P.1241-1248 [in Vietnamese].

Dang Huy Phuong, Le Xuan Canh, Nguyen Truong Son \& Nguyen Dinh Hai. 2013. Mammals recorded in Xuan Lien Nature Reserve, Thanh Hoa Province // Journal of Biology. Vol.35. No.3se. P.26-33.

Dang Ngoc Can, Endo H., Nguyen Truong Son, Oshida T., Le Xuan Canh, Dang Huy Phuong, Lunde D.P., Kawada S.I., Hayashida A. \& Sasaki M. 2008. [Checklist of Wild Mammal Species of Vietnam]. Hanoi: Institute of Ecology and Biological Resources. 400 p. [in Vietnamese].

Dao Nhan Loi, Nguyen Van Viet, Dang Huy Huynh \& Vu Dinh Thong. 2017. Bat species (Mammalia: Chiroptera) recorded from Dien Bien, Lai Chau and Son La Province // Proceedings of the $7^{\text {th }}$ National Scientific Conference on Biology and Ecological Resources, Hanoi. P.255-260.

Darriba D., Taboada G.L., Doallo R. \& Posada D. 2012. jModelTest 2: more models, new heuristics and parallel computing // Nature Methods. Vol.9. No.8. P.772-772.

Ellis S. \& Talukdar B. 2020. Rhinoceros sondaicus. The IUCN Red List of Threatened Species 2020. e.T19495A18493900.

Francis C.M. 2019. A Guide to the Mammals of Southeast Asia. Princeton and Oxford: Princeton University Press. 392 p.

Francis C.M., Borisenko A.V., Ivanova N.V., Eger J.L., Lim B.K., Guillen-Servent A., Kruskop S.V., Mackie I. \& Hebert P.D. 2010. The role of DNA barcodes in understanding and conservation of mammal diversity in South-East Asia // PLoS ONE. Vol.5. No.9. P.1-12.

Fukui D. 2019. Rhinolophus pusillus. The IUCN Red List of Threatened Species 2019. e.T85707059A21994916.

Guo W.P., Lin X.D., Wang W., Tian J.H., Cong M.L., Zhang H.L., Wang M.R., Zhou R.H., Wang J.B., Li M.H. \& Xu J. 2013. Phylogeny and origins of hantaviruses harbored by bats, insectivores, and rodents // PLoS Pathogens. Vol.9. No.2. e1003159.

Gray T.N.E., Hughes A.C., Laurance W.F., Long B., Lynam A.J., O'Kelly H., Ripple W.J., Seng T., Scotson L. \& Wilkinson N.M. 2018. The wildlife snaring crisis: an insidious and pervasive threat to biodiversity in Southeast Asia // Biodiversity and Conservation. Vol.27. P.1031-1037.

Hassanin A., Bonillo C., Tshikung D., Pongombo Shongo C., Pourrut X., Kadjo B., Nakouné E., Vuong Tan Tu, Prié V. \& Goodman S.M. 2020. Phylogeny of African fruit bats (Chiroptera, Pteropodidae) based on complete mitochondrial genomes // Journal of Zoological Systematics and Evolutionary Research. Vol.58. No.4. P.1395-1410.

Hendrichsen D.K., Bates P.J.J., Hayes B.D. \& Walston J.L. 2001. Recent records of bats (Mammalia: Chiroptera) from Vietnam with six species new to the country // Myotis. Vol.39. P.35-122.

Hoang Trung Thanh. 2018. [Study on Horseshoe Bat Genus (Chiroptera: Rhinolophidae) in Vietnam]. PhD Thesis.
Hanoi: Vietnam National University - University of Science. 149 p. [in Vietnamese].

Hoang Trung Thanh, Nguyen Truong Son, Vu Thuy Duong, Nguyen Thanh Luong, Dao Nhan Loi \& Vu Dinh Thong. 2019. [New records and morphological assessment of longnosed fruit bats (Chiroptera: Pteropodidae: Macroglobosus spp.) from Vietnam] // Journal of Biology. Vol.41. No.4. P.117-124 [in Vietnamese].

Irwin D.M., Kocher T.D. \& Wilson A.C. 1991. Evolution of the cytochrome $b$ gene of mammals // Journal of Molecular Evolution. Vol.32. No.2. P.128-144.

IUCN. 2020. The IUCN Red List of Threatened Species. Version 2020-2. Available at www.iucnredlist.org. Accessed 31 July 2020.

Ivanova N.V., Dewaard J.R. \& Hebert P.D. 2006. An inexpensive, automation-friendly protocol for recovering high-quality DNA // Molecular Ecology Notes. Vol.6. No.4. P.998-1002.

Kato A., Oshida T., Nguyen Truong Son, Nguyen Xuan Nghia, Hao Van Luon, Tue Van Ha, Bich Quang Truong, Endo H. \& Nguyen Xuan Dang. 2011. Nest box utility for arboreal small mammals in Vietnam's tropical forest // Russian Journal of Theriology. Vol.10. No.2. P.59-64.

Kearse M., Moir R., Wilson A., Stones-Havas S., Cheung M., Sturrock S., Buxton S., Cooper A., Markowitz S., Duran C. \& Thierer T. 2012. Geneious Basic: an integrated and extendable desktop software platform for the organization and analysis of sequence data // Bioinformatics. Vol.28. P.1647-1649.

Kruskop S.V. 2013. Bats of Vietnam: Checklist and an Identification Manual. Hanoi, Moscow: Joint Vietnamese-Russian Tropical Research and Technological Centre and Zoological Museum of Moscow Lomonosov State University. 299 p.

Kruskop S.V. 2015. Dull and bright: cryptic diversity within the Hipposideros larvatus group in Indochina (Chiroptera: Hipposideridae // Lynx, n.s. (Praha). Vol.46. P.29-42.

Kunz T.H. \& Parsons S. (eds.). 2009. Ecological and Behavioral Methods for the Study of Bats. Second edition. Baltimore: Johns Hopkins University Press. 901 p.

Lekagul B. \& Mcneely J. 1988. Mammals of Thailand. Second edition. Bangkok: Kuru Sapha Ladprao Press. 758 p.

Le Khac Quyet, Rawson B.M., Duc, H., Nadler T., Covert H. \& Ang A. 2020. Rhinopithecus avunculus. The IUCN Red List of Threatened Species 2020. e.T19594A17944213.

Li Y., Li H., Motokawa M., Wu Y., Harada M., Sun H., Mo X. \& Li Y. 2019. A revision of the geographical distributions of the shrews Crocidura tanakae and C. attenuata based on genetic species identification in the mainland of China // ZooKeys. Vol.869. P.147-160.

Lin A.Q., Csorba G., Li L.F., Jiang T.L., Lu G.J., Vu Dinh Thong, Soisook P., Sun K.P. \& Feng J. 2014. Phylogeography of Hipposideros armiger (Chiroptera: Hipposideridae) in the Oriental Region: the contribution of multiple Pleistocene glacial refugia and intrinsic factors to contemporary population genetic structure // Journal of Biogeography. Vol.41. No.2. P.317-327.

Lunde D.P., Musser G.G. \& Nguyen Truong Son. 2003. A survey of small mammals from Mt. Tay Con Linh II, Vietnam, with the description of a new species of Chodsigoa (Insectivora: Soricidae)// Mammal Study. Vol.28. No.1. P.31-46. 
Lunde D. \& Nguyen Truong Son. 2001. An identification Guide to the Rodents of Vietnam. New York: Center for Biodiversity and Conservation, American Museum of Natural History. $80 \mathrm{p}$.

Lunde D.P., Nguyen Truong Son \& Musser G.G. 2007. A survey of small mammals from Huu Lien Nature Reserve, Lang Son Province, Vietnam // Mammal Study. Vol.32. No.4. P.155-168.

Mao X., Tsagkogeorga G., Vu Dinh Thong \& Rossiter S.J. 2019. Resolving evolutionary relationships among six closely related taxa of the horseshoe bats (Rhinolophus) with targeted resequencing data // Molecular Phylogenetics and Evolution. Vol.139. e.106551.

Molur S., Srinivasulu C., Srinivasulu B., Walker S., Nameer P.O. \& Ravikumar L. 2005. Status of South Asian Non-Volant Small Mammals: Conservation Assessment and Management Plan (C.A.M.P.). Workshop Report. Coimbatore, India: Zoo Outreach Organisation / CBSGSouth Asia. 618 p.

Musser G.G., Lunde D.P. \& Nguyen Truong Son. 2006. Description of a new genus and species of rodent $(\mathrm{Mu}-$ rinae, Muridae, Rodentia) from the tower karst region of north-eastern Vietnam // American Museum Novitates. Vol.2006. No.3517. P.1-41.

Nguyen Quang Truong, Ngo Dac Chung, Le Hung Anh, Pham Thi Nhi \& Nguyen Truong Son. 2020. [Curriculum. Methods of Investigation and Monitoring of Animal Biodiversity]. Hanoi: Publishing House of Natural Sciences and Technology. 291 p. [in Vietnamese].

Nguyen Truong Son, Csorba G., Vuong Tan Tu, Vu Dinh Thong, Wu Y., Harada M., Oshida T., Endo H. \& Motokawa M. 2015. A new species of the genus Murina (Chiroptera: Vespertilionidae) from the Central Highlands of Vietnam with a review of the subfamily Murininae in Vietnam // Acta Chiropterologica. Vol.17. No.2. P.201-232.

Nguyen Truong Son, Nguyen Xuan Dang \& Dang Ngoc Can. 2011. [Fauna (Mammalia) diversity of northeast region of Vietnam] // Proceedings of the $4^{\text {th }}$ National Scientific Conference on Ecological and Biological Resources, Hanoi. P.865-875 [in Vietnamese].

Nguyen Truong Son, Nguyen Xuan Dang \& Nguyen Quang Truong. 2002. Bat Survey and Management Plan for Puong Cave, Ba Be National Park, PARC Project VIE/95/ G31\&031, Government of Vietnam (FPD) /UNOPS/ UNDP/Scott Wilson Asia-Pacific Ltd. Hanoi. 29 p.

Nguyen Truong Son \& Vu Dinh Thong. 2008. [The biodiversity of bat fauna in Ba Be National Park and Na Hang Nature Reserve area] // Biodiversity and Genetic Conservation. P.272-275 [in Vietnamese].

Nguyen Truong Son, Vu Dinh Thong, Nguyen Xuan Dang \& Csorba G. 2010. [Conservation status and distribution ranges of some horseshoe and leaf-nosed bat species in Vietnam] // Vietnamese Journal of Biotechnology. Vol.8. No.3A. P.981-990 [in Vietnamese].

Nguyen Truong Son, Vuong Tan Tu, Nguyen Dinh Duy, Nguyen Vu Khoi, Bui Huu Manh, Bui Tuan Hai, Motokawa M., Kawada S.I., Fukui D., Saito H., Hoang Trung Thanh \& Nguyen Van Toan. 2017. [Results of a diverse survey of small mammals (bats, rodents and shrews) in Tay Con Linh Mountain, Vi Xuyen District, Ha Giang Province]. Unpublished Report. 7 p. [in Vietnamese].
Oshida T., Dang Ngoc Can, Nguyen Truong Son, Nguyen Xuan Nghia, Endo H., Kimura J., Sasaki M., Hayashida A., Takano A., Yasuda M. \& Hayashi Y. 2011. Phylogenetic relationship between Callosciurus caniceps and C. inornatus (Rodentia, Sciuridae): Implications for zoogeographical isolation by the Mekong River // Italian Journal of Zoology. Vol.78. No.3. P.328-335.

Oshida T., Lin L-K., Chang S-W., Dang Ngoc Can, Nguyen Truong Son, Nguyen Xuan Nghia, Nguyen Xuan Dang, Endo H., Kimura J., Sasaki M., Hayashida A. \& Takano A. 2015. Mitochondrial DNA evidence suggests challenge to the conspecific status of the hairy-footed flying squirrel Belomys pearsonii from Taiwan and Vietnam// Mammal Study. Vol.40. P.29-33.

Pagès M., Chaval Y., Herbreteau V., Waengsothorn S., Cosson J.F., Hugot J.P., Morand S. \& Michaux J. 2010. Revisiting the taxonomy of the Rattini tribe: a phylogeny-based delimitation of species boundaries // BMC Evolutionary Biology. Vol.10. No.1. e.184.

Ronquist F., Teslenko M., van der Mark P., Ayres D.L., Darling A., Höhna S., Larget B., Liu L., Suchard M.A. \& Huelsenbeck J.P. 2012. MrBayes 3.2: efficient Bayesian phylogenetic inference and model choice across a large model space // Systematic Biology. Vol.61. P.539-542.

Rawson B.M., Roos C., Nguyen Manh Ha, Bleisch W., Geissmann T. \& Fan P.F. 2020. Nomascus nasutus. The IUCN Red List of Threatened Species 2020. e.T41642A17969578.

Shi H., Dong J., Irwin D.M., Zhang S. \& Mao X. 2016. Repetitive transpositions of mitochondrial DNA sequences to the nucleus during the radiation of horseshoe bats $(R h i-$ nolophus, Chiroptera)// Gene. Vol.581. No.2. P.161-169.

Sikes R.S., Gannon W.L. \& the Animal Care and Use Committee of the American Society of Mammalogists. 2016. 2016 Guidelines of the American Society of Mammalogists for the use of wild mammals in research and education // Journal of Mammalogy. Vol.97. No.3. P.663-688.

Simmons N.B. 2005. Order Chiroptera // Wilson D.E. \& Reeder D.M. (eds.). Mammal Species of the World: A Taxonomic and Geographic Reference. Third edition. Baltimore: Johns Hopkins University Press. P.312-530.

Soisook P., Bumrungsri S., Satasook C., Vu Dinh Thong, Si Si Hla Bu, Harrison D.L. \& Bates P.J.J. 2008. A taxonomic review of Rhinolophus stheno and $R$. malayanus (Chiroptera: Rhinolophidae) from continental Southeast Asia: an evaluation of echolocation call frequency in discriminating between cryptic species // Acta Chiropterologica. Vol.10. No.2. P.221-242.

Soisook P., Prajakjitr A., Karapan S., Francis C.M. \& Bates P.J.J. 2015. Anew genus and species of false vampire (Chiroptera: Megadermatidae) from peninsular Thailand // Zootaxa. Vol.3931. No.4. P.528-550.

Srinivasulu C., Racey P.A. \& Mistry S. 2010. A key to the bats (Mammalia: Chiroptera) of South Asia // Journal of Threatened Taxa. Vol.2. No.7. P.1001-1076.

Srinivasulu B. \& Srinivasulu C. 2018. In plain sight: bacular and noseleaf morphology supports distinct specific status of roundleaf bats Hipposideros pomona Andersen, 1918 and Hipposideros gentilis Andersen, 1918 (Chiroptera: Hipposideridae) // Journal of Threatened Taxa. Vol.10. No.8. P.12018-12026.

Steppan S.J. \& Schenk J.J. 2017. Muroid rodent phylogenetics: 900-species tree reveals increasing diversification rates // PLoS ONE. Vol.12. No.8. e0183070. 
Sterling E.J. \& Hurley M.M. 2005. Conserving biodiversity in Vietnam: applying biogeography to conservation research // Proceedings of the California Academy of Sciences. Vol.56. No.9. P.98-118.

Sterling E.J., Hurley M.M. \& Le Duc Minh. 2006. Vietnam: a Natural History. New Haven and London: Yale University Press. 423 p.

Sun H., Dong J., Shi H., Ren M. \& Hua P. 2016. The complete mitochondrial genome of a Chinese rufous horseshoe bat subspecies, Rhinolophus sinicus sinicus (Chiroptera: Rhinolophidae) // Mitochondrial DNA, Part A. Vol.27. No.5. P.3301-3302.

Sun K., Feng J., Zhang Z., Xu L. \& Liu Y. 2009. Cryptic diversity in Chinese rhinolophids and hipposiderids (Chiroptera: Rhinolophidae and Hipposideridae) // Mammalia. Vol.73. No.2. P.135-141.

Thabah A., Rosster S.J., Kingston T., Zhang S., Parsons S., Khin Mya Mya, Zubaid A. \& Jones G. 2006. Genetic divergence and echolocation call frequency in cryptic species of Hipposideros larvatus s.l. (Chiroptera: Hipposideridae) from the Indo-Malayan region // Biological Journal of the Linnean Society. Vol.88. No.1. P.119-130.

Thorington R.W., Koprowski J.L., Steele M.A. \& Whatton J.F. 2012. Squirrels of the World. Baltimore: Johns Hopkins University Press. 459 p.

TordoffA., Baltzer M., Davidson P., Fellowes J., Ha Quy Quynh \& Tran Thanh Tung. 2007. Ecosystem Profile: Indo-Burma Biodiversity Hotspot, Indochina Region. Hanoi, BirdLife International Report. $153 \mathrm{p}$.

Tordoff A., Baltzer M., Fellowes J., Pilgrim J. \& Langhammer P. 2012. Key biodiversity areas in the Indo-Burma hotspot: process, progress and future directions // Journal of Threatened Taxa. Vol.4. No.8. P.2779-2787.

Vietnam Red Data Book. 2007. [Vietnam Red Data Book. Part 1. Animals]. Hanoi: Publishing House of Natural Science and Technology. 515 p. [in Vietnamese].

Vuong Tan Tu, Csorba G., Görföl T., Arai S., Nguyen Truong Son, Hoang Trung Thanh \& Hassanin A. 2015. Description of a new species of the genus Aselliscus (Chiroptera, Hipposideridae) from Vietnam // Acta Chiropterologica. Vol.17. No.2. P.233-254.

Vu Dinh Thong, Puechmaille S.J., Denzinger A., Dietz C., Csorba G., Bates P., Teeling E.C. \& Schnitzler H.U. 2012. A new species of Hipposideros (Chiroptera: Hipposideridae) from Vietnam // Journal of Mammalogy. Vol.93. No.1. P.1-11.
Wilson D.E., Lacher T.E., Jr. \& Mittermeier R.A. (eds.). 2016. Handbook of the Mammals of the World. Vol.6. Lagomorphs and Rodents I. Barcelona: Lynx Edicions. 988 p.

Wilson D.E., Lacher T.E., Jr. \& Mittermeier R.A. (eds.). 2017. Handbook of the Mammals of the World. Vol.7. Rodents II. Barcelona: Lynx Edicions. 1008 p.

Wilson D.E., Lacher T.E., Jr. \& Mittermeier R.A. (eds.). 2018. Handbook of the Mammals of the World. Vol.8. Insectivores, Sloths and Colugos. Barcelona: Lynx Edicions. $710 \mathrm{p}$.

Wilson D.E. \& Mittermeier R.A. (eds.). 2019. Handbook of the Mammals of the World. Vol.9. Bats. Barcelona: Lynx Edicions. 1008 p.

Wu Y., Motokawa M., Harada M., Vu Dinh Thong, Lin L.K. \& Li Y.C. 2012. Morphometric variation in the pusillus group of the genus Rhinolophus (Mammalia: Chiroptera: Rhinolophidae) in East Asia // Zoological Science. Vol.29. P.396-402.

Yoshiyuki M. 1990. Notes on Thai mammals 2. Bats of the pusillus and philippinensis groups of the genus Rhinolophus (Mammalia, Chiroptera, Rhinolophidae) // Bulletin of the National Science Museum Tokyo. Vol.16. P.21-40.

Yusefovich A.P., Artyushin I.V., Raspopova A.A., Bannikova A.A. \& Kruskop S.V. 2020. Attempt to reconstruct phylogeny of the Hipposideros leaf-nosed bats based on nuclear gene markers // Doklady Biological Sciences. Vol.493. P.136-140.

Zhang B., He K., Wan T., Chen P., Sun G., Liu S., Nguyen Truong Son, Lin L. \& Jiang X. 2016. Multilocus phylogeny using topotype specimens sheds light on the systematics of Niviventer (Rodentia, Muridae) in China // BMC Evolutionary Biology. Vol.16. No.261.

Zemlemerova E.D., Bannikova A.A., Lebedev V.S., Rozhnov V.V. \& Abramov A.V. 2016. Secrets of the underground Vietnam: an underestimated species diversity of Asian moles (Lipotyphla: Talpidae: Euroscaptor) // Proceedings of Zoological Institute RAS. Vol.320. No.2. P.193-220.

Zhao L.Z., Bu Y.Z., Zhou H.X., Zhou H.W., Zhang Z.X. \& Niu H.X. 2015. Differences in Hipposideros pomona from three geographical regions in China based on morphology and molecular sequences data // Journal of Mammalogy. Vol.96. No.6. P.1305-1316. 